\title{
GEOCOST: A COMPUTER PROGRAM FOR \\ GEOTHERMAL COST ANALYSIS
}

by

C. H. Bloomster,

Project Director

P.D. Cohn

J.G. De Steese

H.D. Huber

P.N. La Mori

D.W. Shannon

J.R. Sheff

R.A. Walter

February 1975

NOTICE

This report was prepared as an account of work sponsored by the United States Government. Neither the United States nor the United States Energy Research and Development Administration, nor any of their employees, nor any of their contractors, subcontractors, or their employees, makes any warranty, express or implied, or assumes any liability or responsibility for the or assumes any legal liabily or responsibility for the accuracy, completeness or usefulness of any information, apparatus, product or process disclosed, or represents that its use would not infringe privately owned rights.

BATTELLE

PACIFIC NORTHWEST LABORATORIES

RICHLAND, WASHINGTON 99352 


\section{DISCLAIMER}

This report was prepared as an account of work sponsored by an agency of the United States Government. Neither the United States Government nor any agency Thereof, nor any of their employees, makes any warranty, express or implied, or assumes any legal liability or responsibility for the accuracy, completeness, or usefulness of any information, apparatus, product, or process disclosed, or represents that its use would not infringe privately owned rights. Reference herein to any specific commercial product, process, or service by trade name, trademark, manufacturer, or otherwise does not necessarily constitute or imply its endorsement, recommendation, or favoring by the United States Government or any agency thereof. The views and opinions of authors expressed herein do not necessarily state or reflect those of the United States Government or any agency thereof. 


\section{DISCLAIMER}

Portions of this document may be illegible in electronic image products. Images are produced from the best available original document. 
0

$x$ 


\section{SUMMARY}

The GEOCOST computer program is a simulation model which calculates the cost of generating electricity from geothermal energy. GEOCOST will simulate the production of electricity from most types of geothermal resources. It is composed of two principal parts: a reservoir model which simulates the exploration, development, and operation of a geothermal reservoir, and a powerplant model which simulates the design, construction, and operation of the powerplant. Five different powerplant types can be simulated: flashed steam, binary fluid cycle, a hybrid combined flashed steam-binary fluid cycle, total flow, and geopressured reservoirs.

Sensitivity analysis can be performed, using the reservoir and powerplant models, to determine the relative effect of different economic parameters, assumptions, and uncertainties on the cost of generating electricity. The GEOCOST program can be used to:

- determine the economic incentives for specific geothermal research and development programs and projects,

- $\quad$ determine potential economic impacts of uncertainties in technology,

- identify major cost components of geothermal energy, and

- provide a systematic method for assessing the economic potential for each type of geothermal resource and power cycle.

Combined with resource assessment information, GEOCOST can be used to define the potential supply curve (price/quantity relationship) for geothermal energy. This supply curve forms the basis for: 1) assessing the potential role of geothermal energy in competition with other sources of energy, and 2) estimating potential economic incentives for new research and development programs.

GEOCOST can simulate nearly any financial and tax structure through varying the rates of return on equity and debt, the debt-equity ratios, and tax rates. The reservoir model and the powerplant model may have the same or separate financial structures and costs of capital. The plant and reservoir life can be varied over a long period, currently up to 50 years. 
The GEOCOST program calculates the cost of energy based on the principle that the present worth of the revenues will be equal to the present worth of the expenses including investment return over the economic life of the plant and/or reservoir. The present worth factor is determined by the capital structure and rates of return on invested capital for the enterprise. 


\section{CONTENTS}

SUMMARY

LIST OF FIGURES.

LIST OF TABLES.

INTRODUCTION

GEOCOST CAPABILITIES

THE RESERVOIR MODEL.

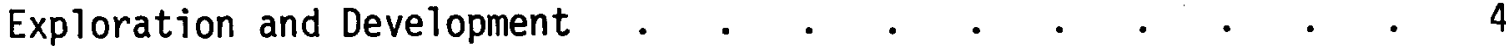

Drilling . . . • • • • • • • • • . . . 6

Reservoir Operation . . . . . . . . . . . . 8

Fluid Transmission and Disposal . . . . . . . . . .8

THE POWERPLANT SYSTEMS MODEL

Steam Plants . . . • • • • • • • . . • . 13

Binary Fluid Cycle Plant . . . . . . . . . . . 16

Hybrid Plant . . . . . . . . . . . . . . 17

Total Flow Plant . . . . . . . . . . . . . . 18

Geopressured Plants . . . . . . . . . . . . . 19

Working Fluid Properties . . . . . . . . . . . 19

Powerplant Capital Costs . . . . . . . . . . . . . 20

Annual Powerplant Expenses and Taxes . . . . . . . . 24

CHEMISTRY •

Material Selection for Field Piping, Well Casings, and
Field Equipment . . . . . . . . . 26

Material Selection for Powerplant Components . . . . . . 27

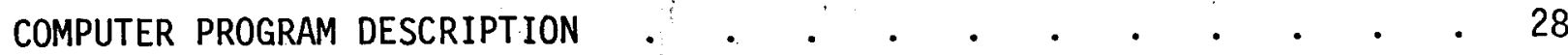

REFERENCES • • • • •

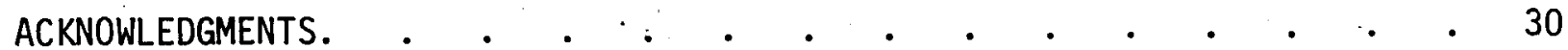

APPENDIX A: Example Printout from Geocost . . . . . . . . A.l 


\section{LIST OF FIGURES}

1 Economic Model for Geothermal Power Systems. . . . . . . 3

2 Flash Steam Plant . . . . . . . . . . . . . 14

3 Sub-Critical Binary Fluid Cycle Power Plant. . . . . . 17

4 Installed Flash Plant Cost (W/o Field or Transmission) versus Plant Power, MWe. . . . . . . . . . . . 27

\section{LIST OF TABLES}

1 Example Drilling Cost Disbribution . . . . . . . . . $\quad$. 7

2 Typical Input to Transmission and Disposal Submodels for 55 MWe Binary Plant. . . . . . . . . . . . . 11

3 Typical Output from Transmission and Disposal Submodels

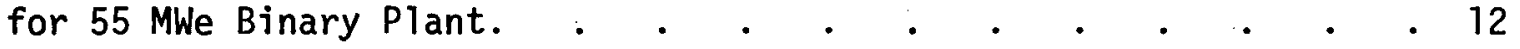

4 Typical Input to Flashed Steam Model . • . . • . . . 15

5 Typical Output from Flashed Steam Mode1. . . . . . . . . 15

6 Heat Exchanger Summary • . . . . . . . . . . . . 18

7 Installed Plant Cost - 10 MWe Binary Isobutane Plant $350^{\circ} \mathrm{F}$ Geothermal Fluid . . . . . . . . . . . . 22

8 Installed Plant Cost - 10 MWe Flash Plant $390^{\circ} \mathrm{F}$ Geothermal Fluid (all water basis) . . . . . . . 23

9 Material Selection for Geothermal Field Equipment . . . . . 26

10 Geothermal Powerplant Material Selection . . . . . . 27 


\section{GEOCOST: A COMPUTER PROGRAM FOR \\ GEOTHERMAL COST ANALYSIS}

\section{INTRODUCTION}

Geothermal energy, a potentially extensive and inexhaustible power source, may eventually be produced from several different types of resources whose characteristics and locations vary widely. Currently, only a few geothermal resources, consisting of dry steam or high temperature water capable of flashing to steam, are used to produce commercial electric power. The economic production of electricity from lower temperature water resources, high brine resources, geopressured resources, and hot, water-deficient resources will require the development of advanced power production technologies. Extensive government and industrial programs are currently underway to develop new resources and demonstrate potential economic power production using advanced technology.

In addition to the resource characteristics and the power recovery technology, the economics of geothermal power is affected by many other factors, such as geophysical and geological exploration and assessment techniques, drilling technology, fluid transmission technology, reservoir development and operation methods, plant operating conditions, tax rates and structure, financial conditions, and rates of return on invested capital.

A computer program, called GEOCOST, has been developed to rapidly and systematically calculate the potential costs of geothermal power. The GEOCOST program incorporates significant economic factors into one systematic framework and provides the flexibility to evaluate their individual economic impacts. This program will be expanded to include nonelectric uses and by-product values. This report describes the scope, capablilities, and flexibility of this computer program. A more detailed report documenting the program and a user's manual will be issued later. 


\section{GEOCOST CAPABILITIES}

The GEOCOST program consists of deterministic cost models which simulate the production of electricity from each type of geothermal resource and powerplant design. These models relate the characteristics of geothermal reservoirs, powerplant designs, and economic factors to the cost of generating electricity. The input data are the wellhead conditions of the geothermal fluid, the powerplant design and capacity, and the design of the wells and well field. GEOCOST also includes an economic data file containing cost and tax data which are updated periodically. The code user may use the built-in data or specify any desired changes to the existing data file.

The flow diagram for GEOCOST is shown in Figure 1. The two main elements of the program are the reservoir and the powerplant models. Linkage between these two models is provided by the fluid transmission and the powerplant system submodels. The powerplant systems submodel calculates the total fluid flow requirements from the reservoir at the wellhead conditions. From this total flow the fluid transmission submodel calculates the number of wells required, pipe lengths and diameters, pumping requirements, and the temperature and pressure drop between the reservoir and the powerplant. The program iterates between the powerplant systems submodel, which calculates the additional flow required under the degraded fluid conditions, and the fluid transmission submodel, which provides the additional flow requirements by adding wells and determines. the new temperature and pressure drop. Iteration continues until the flow to the powerplant converges within preset criteria.

After the required total fluid flow is established, the cash flow associated with the exploration, development, and operation of the reservoir from the beginning of exploration through the life of the powerplant is determined. From the cash flow, the required revenue from energy sales and the unit cost of energy from the reservoir are determined. The GEOCOST program solves for the unit cost of energy by equating the present worth of the revenues and expenses over the useful life of the powerplant. 
Revenues are the product of net energy output and the unit cost. The net annual energy output and annual expenses are derived from the input data. The GEOCOST program provides for specifying any debt-equity ratio, any rate of return on equity, and any rate of interest on bonds. Bond interest expense is, of course, treated as a tax deductible expense. The program provides for incurring debt and equity at the specified ratio when expenses exceed revenues and repaying debt and equity in the same ratio when revenues exceed expenses. At the end of each project, debt and equity are exactly repaid and the project exactly earns the specified rate of return.

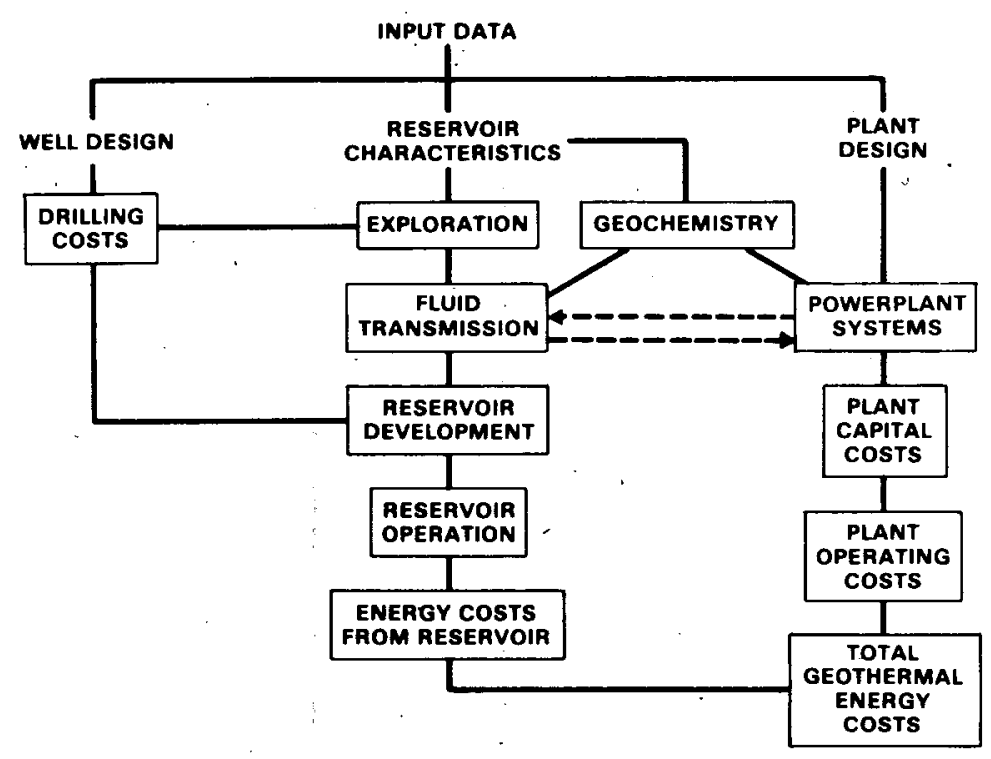

FIGURE 1. Economic Model for Geothermal Power Systems

The revenue to the reservoir is a cost to the powerplant. In the powerplant model, this cost is combined with the other powerplant capital and operating costs to generate the cash flow for constructing and operating the powerplant throughout its useful life. From the powerplant cash flow, the required revenue and unit cost of electricity are determined.

The major elements of the reservoir and powerplant model are discussed in more detail in later sections. An example case showing typical input and output from the program is described in Appendix $A$. 


\section{THE RESERVOIR MODEL}

The reservoir model simulates a firm which explores for, discovers, develops, and operates a geothermal reservoir. The components of the energy costs supplied by the reservoir to the powerplant are computed and shown separately from the powerplant. This permits independent. parametric analyses for the reservoir. The reservoir model includes submodels for simulating exploration and development costs, fluid transmission and disposal costs, drilling costs, and reservoir operating expenses. These submodels are described below:

\section{EXPLORATION AND DEVELOPMENT}

The exploration submodel* simulates the process by which a geothermal resource would be identified and evaluated. The approach used in the exploration model is to reduce the process to a series of discrete steps which have costs and success ratios assigned to them. These steps are: 1) identification of target areas, 2) preliminary land check, 3) preliminary geologic reconnaissance, 4) detailed land check and geologic reconnaissance, 5) identification of drillable sites, 6) exploratory drilling, 7) identification of the producible resource and 8 ) development.

Each of these eight major areas has a task description, time function, associated costs, decision points, and success ratios (finding rates). The reference cost values and finding rates are assigned on the basis of industry estimates. However, these values and rates are variable and sensitivity analyses can be performed to evaluate their relative importance.

On page A.3 of Appendix A, the sample case of the exploration and development costs is given. The desired result is one favorable site to be developed into a producing reservoir. This is indicated by the 1.00 final entry in the Favorable Sites Column. The number of favorable sites listed earlier in the column and associated with the discrete steps is * Part of the input for this (qubmodel has been taken from the works of
R. Greider and M. J. Reed. 
determined by the assigned finding rates, page A.2 of Appendix A. With the exception of the drilling costs which are expensed differently, the Capitalized Costs column represents the unit cost for the associated task for one favorable site. These unit cost figures are input and can be varied.

In the present submodel the discrete steps occur sequentially in time with some specified time overlap. Each one of the steps may contain several sub-steps which occur parallel in time; e.g., Step 5, Identification of Drillable Sites, contains five geophysical exploration techniques which are being applied almost simultaneously. At the present time this is fixed in the submodel.

A purpose of the submodel is to permit the evaluation of different exploration strategies on costs, i.e. to change the time functions and task descriptions and finding rates. The most difficult values to estimate which affect costs are the finding rates because of the limited experience of geothermal exploration data. The model contains a provision to specify the total capacity of the reservoir and the fraction of the reservoir exploration cost which is to be allocated to an individual powerplant. In the example case, the reservoir capacity is 275 MWe and the powerplant size is 55 MWe; therefore, $20 \%$ of the exploration costs were allocated to this powerplant. (See footnote p. A.3).

Al1 reservoir exploration costs are initially capitalized. As the sites are classified unfavorable through the success ratios, the costs which pertained to those sites are written-off as capital losses. The remaining capitalized costs for the favorable site are recovered through a cost depletion account (analogous to straight line depreciation) throughout the producing life of the powerplant.

The development submodel simulates the field development of the proven geothermal reservioir which was identified by the exploration submodel. This submodel accumulates all costs associated with reservoir development. These costs are calculated separately by the drilling, fluid transmission, and fluid disposal submodels. The development submodel includes provision for specifying the percentage of nonproducing 
wells, capacity of injection wells, geometry of the well field, and the fraction of excess producing wells. Input data are shown on page A.3.; Appendix A.

Reservoir development costs include only those costs required to develop and provide the energy supply to the specified powerplant; if the reservoir could support several powerplants, the costs of providing the energy supply to other powerplants would be treated separately. Reservoir development costs for the sample case are shown on p. A.3 under the heading, Field Development.

\section{DRILLING}

A submodel was developed for calculating drilling costs for geothermal wells as a function of the well depth, size of the well at the well bottom, the fraction of the well cased, and the hardness of the material being drilled. The component cost breakdown splits costs into tangible and intangible parts because tax regulations may treat these costs differently.

The GEOCOST program treats producing, nonproducing (dry), and injection wells differently. The tangible part of the producing wells is capitalized and expensed through a depreciation account. The intangible part is expensed immediately. However, the submodel would also permit all drilling costs for producing wells to be capitalized to test the sensitivity of power costs to the differential tax treatment. Nonproducing wells are expensed. A11 costs, both the tangible and intangible, for injection wells are capitalized; these costs are recovered through the depreciation account.

Output of the drilling submodel is the total drilling cost, the tangible and intangible fractions, and the detailed distribution of the drilling costs. The elements of the cost distribution (Table 1) are taken from a 1969 industry cost study. (3) Input data required for the drilling cost calculation are the depth, bottom hole diameter, fraction cased, and average rock hardness. 
Tests of the submodel generally show good agreement between calculations and actual drilling costs. Expansion of the submodel to include functional variations like well temperature, well' pressures, detailed casing structures, detailed hole-size steps, and regional effects is planned. Periodic updating of the model with price indexes is also planned to maintain good agreement between the calculated and the reported drilling costs. This submodel can also be used with a function tabulating and plotting routine ${ }^{(4)}$ already available to generate tables and plots of drilling cost in a stand-alone fashion.

\section{TABLE 1. Example Drilling Cost Distribution \\ (Values rounded to nearest $\$ 1000$ or percent) \\ $\$$ (Thousands) \% of Total}

Payments to Drilling Contractors Road and Site Preparation Transportation

Fuel

Drilling Mud \& Additives

Well Site Logging and Monitoring

A11 Other Physical Tests Logs \& Wireline Evaluation Services

Directional Drilling Service

Perforate

Formation Treating

Cement \& Cementing Service

Casing, Tubing, \& Hardware

Special Tool Rentals

Drill Bits \& Reamers

Wellhead Equipment

Other Equipment \& Supplies

Plugging

Supervision \& Overhead

A11 0ther Expenditures

Total

\begin{tabular}{rr}
86 & 36 \\
5 & 2 \\
2 & 1 \\
1 & - \\
22 & 9 \\
3 & 1 \\
2 & 1 \\
9 & 4 \\
1 & - \\
1 & - \\
2 & 1 \\
11 & 5 \\
61 & 26 \\
7 & 3 \\
4 & 2 \\
2 & 1 \\
4 & 2 \\
1 & - \\
5 & 2 \\
8 & 3 \\
\hline 238 & 100
\end{tabular}




\section{RESERVOIR OPERATION}

The operation submodel simulates the operation of the required reservoir capacity throughout the life of the powerplant. It is composed of several annual costs, e.g. royalty payments, injection costs, taxes, overhead and management, and well maintenance, which can be varied to examine their effect on the unit cost of power. Additionally, the operations submodel includes operating costs for the transmission and disposal systems as well as replacement well drilling and redrilling costs. All of the operating costs are assumed to be constant each year throughout the life of the powerplant. As with reservoir development costs, operating costs refer only to a single powerplant. All annual operating costs are expensed except for interim capital replacements. These are capitalized and recovered through the depreciation account. The tangible part of replacement producing wells is treated analogously to interim capital replacements. The intangible part of replacement producing wells is treated as an operating expense.

\section{FLUID TRANSMISSION AND DISPOSAL}

The fluid transmission submodel simulates the conduction of the geothermal fluid, either water or steam, from the wellhead to the powerplant. This submodel calculates the pipeline diameter, length, number of producing wells required, the well field layout, pumping requirements, and the costs of the transmission piping system, pumps, and associated equipment. It also calculates the fluid temperature, pressure, viscosity, density, and enthalpy on a node-by-node basis during transport from the wellhead to the plant. This submodel has been used to produce an economic description of a steam transmission system which correlates well with practice at The Geysers field.

The disposal submodel is analogous to the transmission submodel and simulates the conduction of water effluent from the wellheads and the powerplant to the injection well field. It calculates the effluent pipeline diameter and length, number of injection wells, injection well field layout, and the costs of the disposal piping system and associated equipment. Because of their similarity, only the transmis!sion submodel is described in detail. 
The cost of the fluid transmission and disposal systems establish the optimum powerplant size for a given geothermal resource. In general, powerplant costs show economies of scale and, therefore, decreased unit energy costs with increased plant size. However, because more wells are required which extends the distance of fluid transmission, pipeline and pumping costs increase very rapidly with plant size. The optimum plant size occurs when the marginal gain resulting from lower unit cost for larger powerplants is exactly offset by the marginal loss resulting from increasing unit costs for transmission and disposal.

Cost expressions for pipe, insulation, and appropriate pipeline components have been formulated for single phase flow conditions with water and steam. Pipeline costs are based on 1974 building construction cost data. Material, fitting and installation costs are expressed as a function of the pipe diameter and a scaling exponent. To reduce the influence of the transmission and disposal system on overall plant costs and performance, an optimization subroutine was developed to select optimum pipe diameters. Optimum pipe diameters are determined from economic trade-offs between pipeline cost, the value of friction energy lost in the pipeline, pump and drive motor capital costs, and the cost of power consumed in operating the pumps and motors.

The reservoir is described by a matrix of wellhead sites which are the nodes of the pipeline simulation. The wellheads are connected with pipe runs parallel to equilateral triangular coordinate axes. Pipeline diameters are sized and pipe scheduled on a node-by-node basis. Initially the economic optimization criteria identify the smallest practical diameters. An iterative routine changes the pipe diameter to avoid unacceptable fluid quality and correlates the pipeline design with fluid and thermodynamic conditions along its length. Pipe runs between nodes are sized by fluid mass flow rate, density, and viscosity. Multiple wellhead flashing is accommodated by up to four separate transmission lines for each quality of steam or hot water. 
An insulation cost submodel was derived for the fluid transmission system. Vendor cost and heat conduction data were correlated to produce generalized cost and heat loss expressions. Of particular interest was the demonstration that an expression of the form,

$$
h=\frac{a D^{b} T^{c}}{t^{d}}
$$

$$
\begin{aligned}
\text { where } & h \text { is heat loss } \\
D & \text { is pipe diameter } \\
T & \text { is pipe temperature } \\
t & \text { is insulation thickness }
\end{aligned}
$$

and $a, b, c$, and $d$ are constants,

summarizes a vast amount of vendor-supplied engineering data which are usually available only in tabular form. Cost expressions for peripheral equipment such as flashers, separators, valves, pumps, motors and instrumentation were developed separately for inclusion with the transmission and disposal submodels.

The initial costs for the transmission and disposal systems are capitalized. Cost recovery is through the depreciation account using the sum-ofthe-year's digit method.

Typical input to the transmission and disposal submodels is shown for a $55 \mathrm{MW}_{\mathrm{e}}$ isobutane cycle binary plant in Table 2. The corresponding output is shown in Table 3 . 
TABLE 2. Typical Input to Transmission and Disposal Submodels for $55 \mathrm{MW}_{\mathrm{e}}$ Binary Plant

Input Required for All Geothermal Plant Types (a)

Geothermal plant type ( $1=$ binary, 2 = steam, 3 = hybrid $)$ Average well flow rate $\left(1 b_{\mathrm{m}} / \mathrm{sec}\right)$

Well spacing (acres)

Wellhead fluid temperature $\left({ }^{\circ} \mathrm{F}\right)$

Wellhead fluid pressure (psia)

Well Tife (yrs)

Fraction nonproducing wells

Fraction excess producing wells

Total flow rate required by plant $(1 \mathrm{~b} / \mathrm{hr})$

Maximum number of rows in well layout matrix

Maximum number of columns in well layout matrix

Transmission maintenance factor

Disposal maintenance factor

Fraction of pipe that can be salvaged

Plant net heat rate for fluid transmission line(s) $\left(\mathrm{kW}_{t} / \mathrm{kW}_{\mathrm{e}}\right)$

Annualized cost factor

Plant Availability (hrs/yr) (85\%)

6154802

Value of output electric energy $(\$ / \mathrm{kW}-\mathrm{hr})$

Optional injection wells using well water effluent $(0=$ no, $1=$ yes $)$

Optional injection wells using plant water effluent $(0=$ no, $1=$ yes $)$

Ratio of injection/production well flow rate

14.28

Distance from well field to injection wells $(\mathrm{m})$

0.11

Distance from plant to injection wells (m)

$\mathrm{Plant}$ water effluent temperature $\left({ }^{\circ} \mathrm{F}\right)$

0.02

Plant water effluent pressure (psia)

Plant water effluent flow rate $\left(1 \mathrm{~b}_{\mathrm{m}} / \mathrm{sec}\right)$

Additional Input Required for Steam and Hybrid Plants

Location of flashers ( $0=$ wellhead, $1=$ plant $)$

Number of flashing stages (NFLASH)

Number of steam lines into powerplant (NFLOW)

Steam flow rate required by plant in each steam 1 ine $\left(1 b_{m} / h r, I=1, N F L O W\right)$

Flashed steam temperatures ( $\left.{ }^{\circ} \mathrm{F}, I=1, \mathrm{NFLASH}\right)$

Flashed steam pressure (psia, $I=1, \mathrm{NFLASH}$ )

Effluent water temperature after final flashing $\left({ }^{\circ} \mathrm{F}\right)$

Effluent water pressure after final flashing (psia)

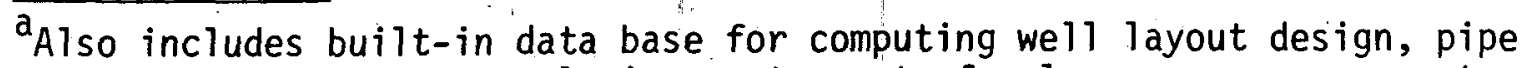
schedule, pipe cost, insulation cost, cost of valves, gauges, separators, flashers, electric motors, and booster pumps; also data base for computing nodal temperature drop, nodal pressure drop, and electrical power required by booster pumps. 


\section{TABLE 3. Typical Output from Transmission and Disposal Submodels for $55 \mathrm{MW}_{\mathrm{e}}$ Binary Plant}

Number of fluid transmission lines to plant

Number of producing wells

ivumber of nonproducing wells

Throttled average well flow rate $(1 \mathrm{~b} / \mathrm{sec})$

Pipe length between nodes ( $\mathrm{m}$ )

Total transmission line and component costs (\$)

Pipe

Insulation

Wellhead valves

Pressure gauges

Rock separators

Cyclone separator

Wel thead flashers

Wellhead steam separators

Transmission booster pumps for water line

Transmission maintenance cost $(\$ / y r)$

Transmission capital replacement rate (annua))

Final fluid conditions in transmission line at plant inlet

Flow rate $(1 \mathrm{bm} / \mathrm{hr})$

Temperature $\left({ }^{\circ} \mathrm{F}\right)$

Pressure (psia)

Number of fluid injection lines from plant to injection wells

Number of injection wells

Total injection line cost (\$)

Injection maintenance cost ( $\$ / y r)$

Injection capital replacement rate (annual)

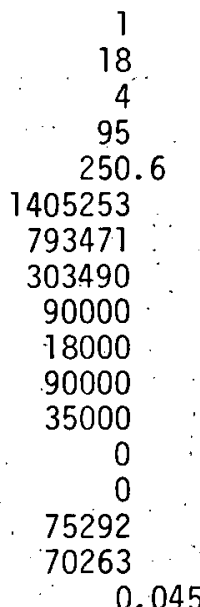

6.154802

391.7

234.7

1

8

678188

33909

0.045

Node-by-node matrices, illustrated here by showing the inlet properties at the first node and the exit properties from the last node prior to plant inlet (d) Matrix of number of wells upstream from each node $\begin{array}{cc}\text { First Node } & \frac{\text { Last Node }}{1} \\ 1 & 18 \\ 18\end{array}$

Matrices of well head fluid conditions

Temperature $\left({ }^{\circ} \mathrm{F}\right)$

Pressure (psia)

Viscosity $(1 \mathrm{~b} / \mathrm{ft}-\mathrm{sec})$

Density $\left(1 \mathrm{~b} / \mathrm{ft}^{3}\right)$

Matrices of nodal fluid conditions

Temperature $\left({ }^{\circ} \mathrm{F}\right)$

Pressure (psia)

Viscosity $(1 \mathrm{~b} / \mathrm{ft}-\mathrm{sec})$

Density $\left(1 \mathrm{~b} / \mathrm{ft}^{3}\right)$

Matrix of nodal internal pipe diameters (in)

Matrix of nodal pipe insulation thicknesses (in)

$\begin{array}{cl}392 & 392 \\ 256.65 & 256.65 \\ 10.18 \mathrm{E}-5 & 10.18 \mathrm{E}-5 \\ 54.15 & 54.15 \\ & \\ 392 & 391.7 \\ 256.65 & 236.4 \\ 9.00 \mathrm{E}-5 & 10.18 \mathrm{E}-5 \\ 54.15 & 54 \\ 7.1 & 26.7 \\ 5 & 6\end{array}$

(a) Output for each plant cycle-transmission iteration and for each transmission line from well field to plant. Output results shown are for transmission line to plant. For the final plant cycle-transmission iteration satisfying the convergence criterion, analogous results are output for the injection line(s) and injection wells.

(b) The model operates on the assumption that all wells in the reservoir have the same average properties. However, variable well properties could be accommodated with minor code modification. 


\section{THË POWERPLANT SYSTEMS MODEL}

The powerplant systems model simulates a firm which designs, constructs, and operates an electric generating plant. In this simulation, the firm purchases the energy supply from the firm which operates the geothermal reservoir. The powerplant systems model includes (1) submodels which simulate different power cycles and determine the fluid flow rates, thermodynamic properties, and the internal plant electrical consumption; and (2) functions for estimating major equipment and construction costs, operating and maintenance costs, water treatment costs, and outage rates. The major elements of this model are described below.

The geothermal powerplant systems model simulates the generation of electricity from several different types of power cycles. Based on the thermodynamic state of the geothermal fluid as it leaves the fluid transmission lines, this model predicts the mass flow rate of the geothermal fluid required for a specified electrical output. In addition to the fluid mass flow rate, the model also determines the physical and thermodynamic properties of numerous working fluids, the state points in the thermodynamic cycle being used, the size of various powerplant components, and the design performance of the powerplant.

Five different powerplant types can be simulated: flashed steam, binary fluid cycle, hybrid (flashed steam/binary fluid cycle), total flow and geopressured reservoirs. These powerplants are discussed in the following paragraphs.

\section{STEAM PLANTS}

The flashed steam submodel simulates electrical power generation from relatively high temperature reservoirs. The steam for this powerplant is generated by flashing hot geothermal water down to a reduced pressure. This flashed steam is subsequently expanded through a steam turbine which is coupled to an electrical generator. As an option, the submodel will also handle steam which is extracted directly from a geothermal well, simiIar to The Geysers area in California. After the steam is expanded through 
the turbine, it is condensed in a barometric, contact-type condenser which is supplied with cooling water from a forced-draft, wet cooling tower. Noncondensible gases contained in the exhaust steam are removed from the condenser with a two-stage steam jet ejector. Excess water remaining after cooling tower evaporation is reinjected into the geothermal reservoir. The electrical consumption is calculated for internal power usage for cooling tower fans, cooling water pumps, and pumps for the geothermal fluid. This internal consumption is subtracted from the gross electrical output to yield the net electrical output. The flashed steam powerplant is illustrated in Figure 2. Typical input of this model is shown in Table 4.

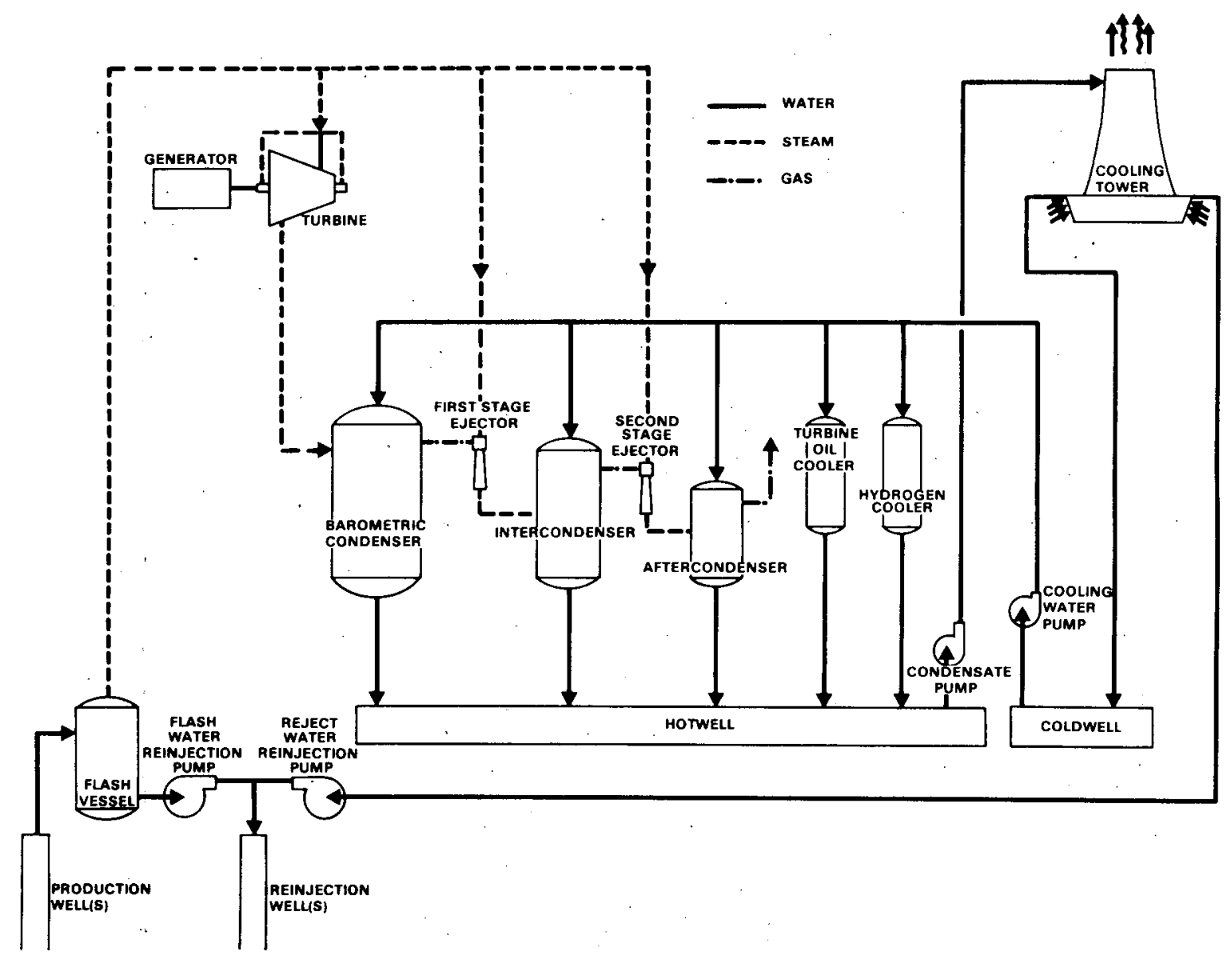

FIGURE 2. Flash Steam Plant 
TABLE 4. Typical Input to Flashed Steam Model

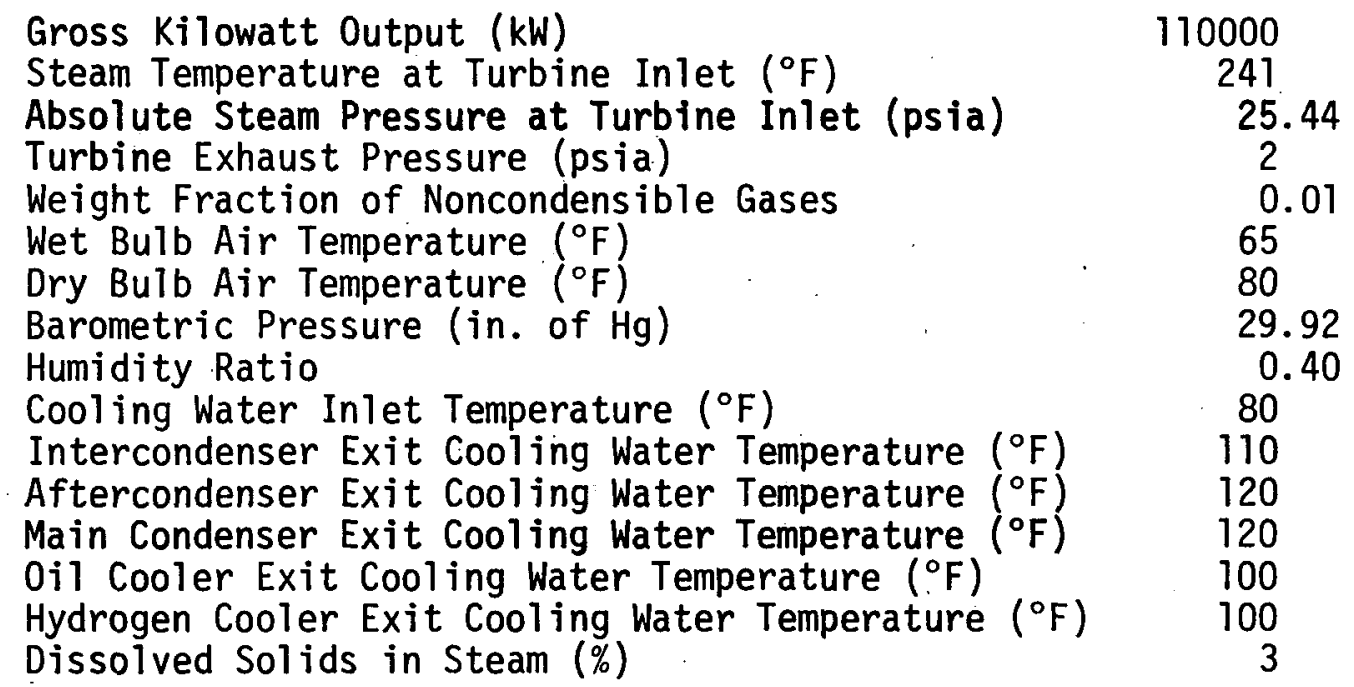

$\begin{array}{lc}\text { Gross Kilowatt Output (KW) } & 110000 \\ \text { Steam Temperature at Turbine Inlet }\left({ }^{\circ} \mathrm{F} \text { ) }\right. & 241 \\ \text { Absolute Steam Pressure at Turbine Inlet (psia) } & 25.44 \\ \text { Turbine Exhaust Pressure (psia) } & 2 \\ \text { Weight Fraction of Noncondensible Gases } & 0.01 \\ \text { Wet Bulb Air Temperature }\left({ }^{\circ} \mathrm{F}\right) & 65 \\ \text { Dry Bulb Air Temperature }\left({ }^{\circ} \mathrm{F}\right) & 80 \\ \text { Barometric Pressure (in. of } \mathrm{Hg} \text { ) } & 29.92 \\ \text { Humidity Ratio } & 0.40 \\ \text { Cooling Water Inlet Temperature }\left({ }^{\circ} \mathrm{F} \text { ) }\right. & 80 \\ \text { Intercondenser Exit Cooling Water Temperature }\left({ }^{\circ} \mathrm{F}\right) & 110 \\ \text { Aftercondenser Exit Cooling Water Temperature }\left({ }^{\circ} \mathrm{F}\right) & 120 \\ \text { Main Condenser Exit Cooling Water Temperature }\left({ }^{\circ} \mathrm{F}\right) & 120 \\ \text { Oil Cooler Exit Cooling Water Temperature }\left({ }^{\circ} \mathrm{F}\right) & 100 \\ \text { Hydrogen Cooler Exit Cooling Water Temperature }\left({ }^{\circ} \mathrm{F}\right) & 100 \\ \text { Dissolved Solids in Steam }(\%) & 3 \\ & \\ \text { Typical output from the flashed steam model using the above input is listed } \\ \text { in Table 5. }\end{array}$ in Table 5.

TABLE 5. Typical Output from Flashed Steam Model

Cooling Water Flow Rates

Intercondenser Flow $(\mathrm{lb} / \mathrm{hr})$

Aftercondenser Flow $(1 \mathrm{~b} / \mathrm{hr})$

$2,305,000$

$1,960,000$

Turbine 0il Cooler ( $1 \mathrm{~b} / \mathrm{hr}$ )

93,760

Hydrogen Generator Cooler (1b/hr)

356,300

Condenser Flow ( $\mathrm{ib} / \mathrm{hr}$ )

Temperature of Cooling Water into Tower $\left({ }^{\circ} \mathrm{F}\right)$

$69,300,000$

Internal Losses

KW Required for Fans ( $\mathrm{kW}$ )

Condensate Pumps to Cooling Tower. (kW)

2,435

Cooling Water Pumps (kW)

1,539

Cooling Tower Reinjection Pump (kW)

3,024

Flash Reinjection Pumps (kW)

119

KW Required for Vacuum Pump on Condenser (kW)

3,558

KW Required for Scrubber Pump (kW)

KW Required for Water Pressurizing Booster Pumps (kW) 
TABLE 5. (Cont'd)

\section{Overall Results}

Actual Gross Steam Rate (1b/kW-hr)

Actual Gross Heat Rate (Btu/kW-hr)

Actual Net Steam Rate (1b/kW-hr)

Actual Net Heat Rate (Btu/kW-hr)

Average Net Steam Rate (1b/kW-hr)

Average Net Heat Rate (Btu/kW-hr)

Steam Flow to Turbine ( $\mathrm{lb} / \mathrm{hr}$ )

Total Steam Flow (1b/hr)

Total Well head Flow (1b/hr)

Total Cooling Water Requirements (1b/hr)

Cooling Tower Air Flow Rate (cfm)

Cooling Tower Evaporation Rate (1b/hr)

Heat Load of Cooling Tower (Btu/hr)

Reinjection Rate-Blowdown (1b/hr)

Flash Reinjection Rate (1b/hr)

Internal Power Consumption (kW)

Net Power Output (kW)

$$
\begin{gathered}
27.9 \\
32,440 \\
32.3 \\
37,440 \\
32.3 \\
37,450 \\
3,073,000 \\
3,211,000 \\
25,770,000 \\
74,020,000 \\
16,810,000 \\
2,458,000 \\
30,010,000 \times 10^{2} \\
752,600 \\
22,550,000 \\
10,670 \\
99,330
\end{gathered}
$$

\section{BINARY FLUID CYCLE PLANT}

In the binary fluid cycle plant, the geothermal fluid extracted from the reservoir is maintained as a liquid and is passed through a series of heat exchangers. Thermal energy is transferred from the hot water to a working fluid. The working fluid is vaporized and superheated and then expanded through a turbine. The cooled geothermal fluid is reinjected into the reservoir after passing through the heat exchangers. A schematic of this powerplant is shown in Figure 3 . Both subcritical and supercritical binary cycles are available in this submodel. The input to the binary plant submodel is similar to that of the flashed steam, apart from the additional input of working fluid type and maximum working fluid temperature. Output of the binary plant submodel includes the same type of information as shown in Table 5, with the addition of data on the waterworking fluid heat exchangers. Table 6 shows typical data from a 10 MW binary plant using geothermal water at an initial temperature of $392^{\circ} \mathrm{F}$ and isobutane as a working fluid. 


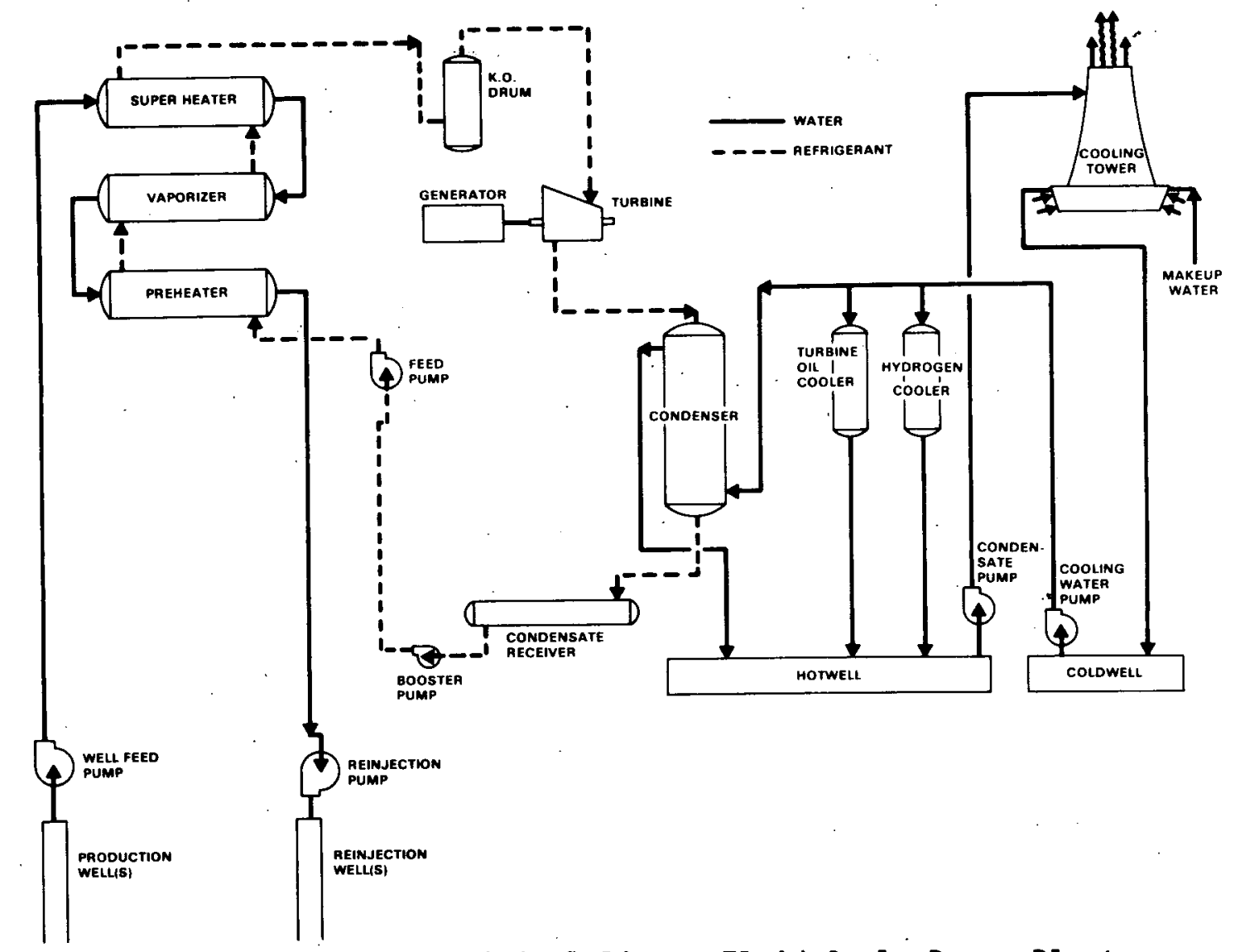

FIGURE 3. Sub-Critical Binary Fluid Cycle Power Plant

This type of powerplant is frequently suggested when the geothermal fluid is highly saline, contains large quantities of noncondensible gases, or is at too low a temperature to justify flashing to steam.

\section{HYBRID PLANT}

The hybrid plant submodel is a combination of the flashed steam and the binary fluid cycle plant submodels, where the flashed steam section serves as the primary power generator, and the binary section is used as a bottoming cycle. Output of the hybrid plant model is similar to that of the flashed steam and binary cycle plant models. 
TABLE 6. Heat Exchanger Summary

Preheater Vaporizer Super Heater

Inside Heat Transfer Coefficient

$$
\text { (Btu/hr-ft }{ }^{2}-{ }^{\circ} \mathrm{F} \text { ) }
$$

Tube Inside Diameter ( $f t)$

Tube Outside Diameter ( $\mathrm{ft}$ )

Number of Tubes

Equivalent Outside Diameter ( $\mathrm{ft}$ )

Outside Heat Transfer Coefficient

$$
\text { (Btu/hr-ft } \left.{ }^{2}-{ }^{\circ} \mathrm{F}\right)
$$

Overall Heat Transfer Coefficient

$$
\begin{aligned}
& \quad\left(B t u / h r-f^{2}-{ }^{\circ} \mathrm{F}\right) \\
& \text { Heat Transfer Area }\left(f t^{2}\right) \\
& \text { Heat Transfer Length }(\mathrm{ft}) \\
& \text { Working Fluid } \\
& \text { Inlet Temperature }\left({ }^{\circ} \mathrm{F}\right) \\
& \text { Inlet Pressure (psia) } \\
& \text { Inlet Enthalpy (Btu/lb) } \\
& \text { Outlet Temperature }\left({ }^{\circ} \mathrm{F}\right) \\
& \text { Outlet Pressure (psia) } \\
& \text { Outlet Enthalpy (Btu/lb) }
\end{aligned}
$$

Water

$$
\begin{aligned}
& \text { Inlet Temperature }\left({ }^{\circ} \mathrm{F}\right) \\
& \text { Inlet Pressure (psia) } \\
& \text { Outlet Temperature }\left({ }^{\circ} \mathrm{F}\right) \\
& \text { Outlet Pressure (psia) }
\end{aligned}
$$

2572

$$
0.1
$$

0.11

83

0.05

2461

7848

2576

$\begin{array}{rcc}929.8 & -- & 1005 \\ 2573 & -- & 1222 \\ 89.4 & 15.2 & 40.5 \\ & & \\ 89.4 & 262.7 & 262.7 \\ 476.2 & 476.2 & 476.2 \\ -792.5 & -656.3 & -612.5 \\ 262.7 & 262.7 & 350 \\ 476.2 & 476.2 & 476.2 \\ -656.3 & -612.5 & -544\end{array}$

292.7

331.5

392

305.5

280.5

255.5

172.4

292.7

331.5

280.5

255.5

230.5

\section{TOTAL FLOW PLANT}

The total flow submodel is based on work currently underway at the Lawrence Livermore Laboratories. ${ }^{(5)}$ The thermal energy contained in a twophase mixture of geothermal fluid is converted to kinetic energy by expansion through a converging-diverging nozzle. This kinetic energy 
drives a modified impulse turbine which is, coupled to a generator. The total flow powerplant provides output similar to the other powerplant submodels.

\section{GEOPRESSURED PLANTS}

The geopressured plant submodel is specifically designed to extract energy from highly pressurized, relatively low temperature, geothermal reservoirs. These reservoirs are commonly called geopressured regions. Two unique aspects of the geopressured submodel are the potential utilization of the kinetic energy and methane, which are contained in the geopressure fluid. The geopressured plant can be simulated as either a binary fluid cycle plant or total flow plant. The submodel permits methane to be either sold or used to superheat the working fluid for the binary fluid cycle.

\section{WORKING FLUID PROPERTIES}

Numerous fluid properties are required in order to operate the five different powerplants discussed in the preceding paragraphs. A major portion of the powerplant systems model consists of the calculation of thermodynamic and physical properties of working fluids. Working fluids which are now available for use in the model include water, $R-11, R-12, R-$ $21, R-22, R-113, R-114$, isobutane and n-butane. The capability exists for the addition of other working fluids such as ammonia, propylene, ethylene, and numerous fluorocarbons. Physical properties for these working fluids are stored in the model as functions of phase and temperature. Properties available from the data matrix include specific heat, thermal conductivity, density, viscosity, critical pressure, critical temperature, surface tension, and molecular weight.

Thermodynamic properties of the working fluids are calculated using two equations of state, not tabulated data. The Martin-Hou equation of state was used for the fluorocarbons and the Benedict-Webb-Rubin (BWR) equation of state was used for hydrocarbons. $(6,7)$ Properties which can 
be calculated using these equations of state include pressure (psia), temperature $\left({ }^{\circ} R\right)$, enthalpy $(B t u / l b)$, entropy $\left(B t u / l b /{ }^{\circ} R\right)$, and specific volume $\left(\mathrm{ft}^{3} / \mathrm{lb}\right)$. These properties are used in the model to formulate the thermodynamic power cycle from various state points. The predicted thermodynamic properties agree well with tabular data. With the capability of determining properties of various working fluids, the powerplant systems model is able to evaluate various geothermal powerplant systems with varying source and sink temperatures for numerous working fluids.

POWERPLANT CAPITAL COSTS

The capital cost submodel generates capital cost data for geothermal powerplants. Capital costs as a function of power level and/or geothermal fluid or other process conditions are computed specifically for the powerplant, heat rejection system, and the switchyard. Equipment cost data were gathered from two primary sources: industry vendors and utility operators of geothermal powerplants. Binary plant costs were developed by analyses of the several cost proposals, estimates, and papers for these plants. The major component data were also checked with potential vendors. Much of the published cost data were pre-1974 and these were updated with indices to 1974 costs.

Total powerplant and installed equipment cost correlations (in 1974 dollars) were prepared by analyzing cost data for major plant components. Plant costs were correlated primarily as a function of power level and/or steam or working fluid flow rates. Costs for established dry steam and flash plants are shown in Figure 4. Estimates for total steam plant costs under similar temperature and flow conditions as generated from the individual cost equations correlated well with these data. The dependence of plant component costs as a function of steam and/or working fluid mass flow rates provides the sensitivity of total plant costs to geothermal fluid conditions. The cost routines are now operable for the flash; binary, and hybrid paints. 


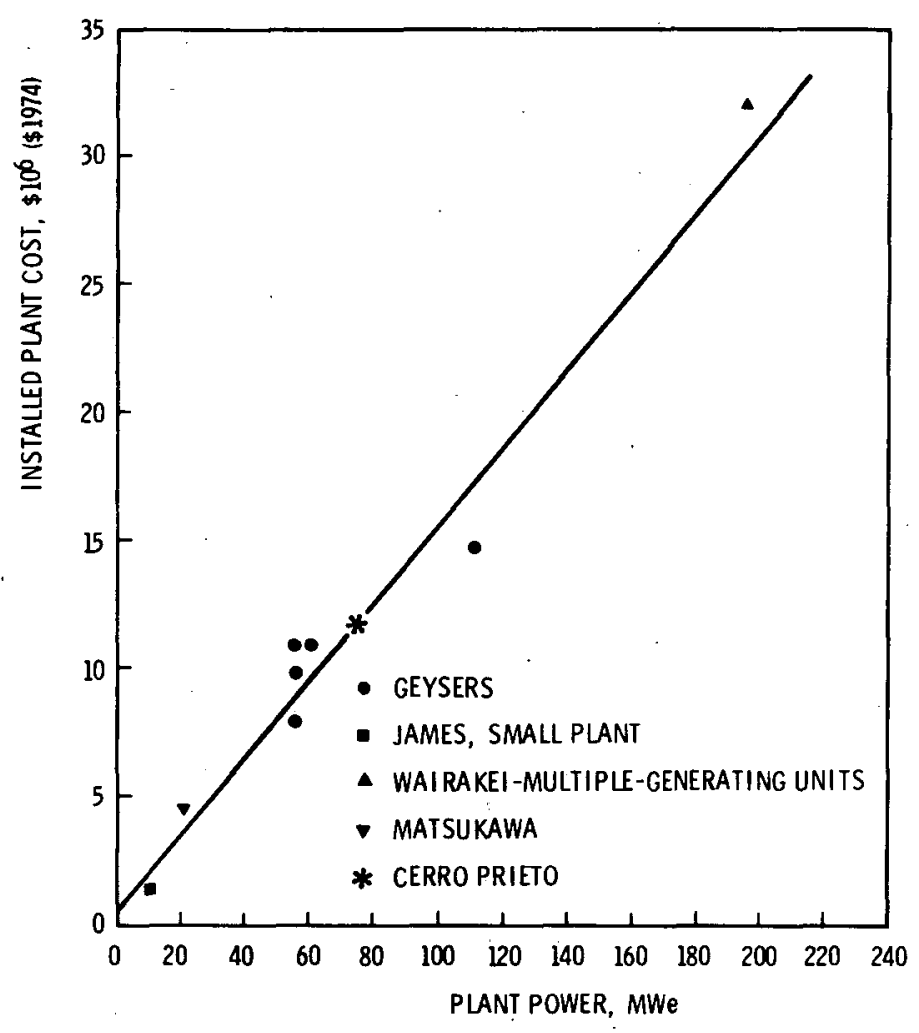

FIGURE 4. Installed Flash Plant Cost (w/o Field or Transmission) versus Plant Power, MWe

The flash plant uses the geothermal energy in the following modes which are reflected in the options built into the flash plant and reservoir cost routines: (1) steam flashed and separated (single flash cycle) or dry steam at the wellhead, (2) water transmitted to the plant and flashed and separated (single flash cycle) at the plant site, and (3) multiple flash combinations of options 1 and 2 . The binary plant uses the geothermal fluid as a heat source for the binary working fluid. The hybrid plant uses both flashed steam as a working fluid and the flash effluent (bottoms) of a heat source for a binary cycle. Major component costs are set up in a decimal indexing system specific to each plant type. Cost data are correlated to the simple equation:

$$
\text { Installed cost }=a+b(x)^{s} \text {, }
$$


where

a reflects fixed costs and

b reflects materials, equipment, and installation dependent costs,

$s$ is a size scale factor, and

$x$ is the independent variable such as geothermal fluid flow rate, plant power, working fluid flow rate or other process flow rate.

Table 7, from the GEOCOST printout, illustrates the typical output for the plant cost model. A $350^{\circ} \mathrm{F}$ geothermal fluid binary plant is shown in this example. The different account categories treat the major plant components and costs. The decimal break-down within these categories provides the economic detail for specific equipment and/or cost items. Table 8 presents the same data for a $390^{\circ} \mathrm{F}$ geothermal fluid flash plant. The high cost of this plant is primarily due to the small plant size and low enthalpy of the flashed steam and the resultant high steam flow requirements.

TABLE 7. Installed Plant Cost - 10 MWe Binary Isobutane Plant $350^{\circ} \mathrm{F}$ Geothermal Fluid $(500,000 \mathrm{lb} / \mathrm{hr} / \mathrm{we} 11$; isobutane $=0.98 \mathrm{E} 6 \mathrm{lb} / \mathrm{hr}$; total geothermal F.R. $=7.45 \mathrm{E} 6 \mathrm{~Tb} / \mathrm{hr}$ )

Account

$1.0 \quad$ Powerplant

$1.1 \quad$ Piping, Insulation, \& Pumps 135

1.2 Crane 98

1.3 Turbo Generator ... 545

1.5 Vapor Generator (Boiler) 262

1.7 Auxiliary Heat Exchanger : $\quad 115$

1.9 Misc. Process Support Equip. .... . 26

1.10 Instrumentation and Controllers 101

1.12 Electrical Support and Equip. 119

1.16 Condenser 171

1.17 Installation Testing 16

$1.18 \quad$ Buildings, Foundations, and
Support Equipment

1.99 Total $1.0 \quad 1778$ 
TABLE 7. Cont'd

2.0 Heat Rejection System (Cooling Towers)

2.1 Cooling Tower System

2.99 Total 2.0

$3.0 \quad$ Switch Yard

3.99 Total 3.0

$5.0 \quad$ Other Costs

5.1 Engineering and Design 258

5.2 Administration and Indirect Costs : 207

5.99 Total $5.0 \quad 465$

Total Powerplant Cost $\quad 3047$

TABLE 8. Installed Plant Cost

10 MWe Flash Plant

$390^{\circ} \mathrm{F}$ Geothermal Fluid (a11 water basis)

Account

Costs

$(\$ 1000)$

1.0 Powerplant

1.1

Piping, Insulation, \& Pumps

Crane

134

Turbo Generator

1500

1.3

Flashers (Plant Located Units)

208

1.9

1.10

Misc. Process Support Equip.

Instrumentation and Controllers

134

Electrical Support and Equip.

119

1.16

Condenser

447

Installation Testing

1.18

Buildings, Foundations, and Support Equipment

Gas Ejectors (Steam Driven)

1.99

Total 1.0

$\frac{111}{3009}$

2.0

Heat Rejection System (Cooling Towers)

2.1

Cooling Tower System

652

2.99

Total 2.0

652

3.0 Switch Yard

3.99 Total 3.0

200

5.0 Other Costs

5.1 Engineering and Design 386

5.2 Administration and Indirect Costs 309

5.99 Total 5.0 . 695

Total Powerplant Cost $\quad 4556$ 


\section{ANNUAL POWERPLANT EXPENSES AND TAXES}

Annual powerplant expenses include four items: operating costs, maintenance costs, interim capital replacements, and property insurance. In addition, the program provides for revenue taxes, property taxes, and state and Federal income taxes. The expression for annual operating costs is a function of plant size and was derived from utility statistics: operating cost $=1455\left(\mathrm{MW}_{\mathrm{e}}\right)^{0.9}$. The annual maintenance costs are a function of plant capital cost: maintenance cost $=0.004$ (plant capital cost). Interim capital replacements are a function of plant capital cost: interim capital replacement $=K$ ( $p$ lant capital cost). The rate, $K$, is a variable specified by input. Property taxes and property insurance are similarly functions of plant capital cost and each rate is also variable.

The program provides for a gross revenue tax at a rate specified by input. The program also provides for both state and Federal income taxes, each rate specified through input. The program treats state income taxes as deductible expenses for Federal income taxes; but Federal income taxes are not deductible for state income taxes.

Plant capital costs, including interim capital replacements, are recovered through the depreciation account. Accounting for depreciation is based on sum-of-the-year's digit method. 


\section{CHEMISTRY}

The chemistry submodel treats the effects of geothermal fiuid temperature, steam/water ratio, $\mathrm{pH}$, silica, $\mathrm{H}_{2} \mathrm{~S}$, salinity, $\mathrm{CO}_{2}$, and calcite $\left(\mathrm{CaCo}_{3}\right)$. Material selection, costs, and lifetimes, as well as process and maintenance costs options, are produced by the submodel for cost effectiveness comparison and evaluation.

The chemistry submodel analytically describes the various components of plant construction, operating. expenses, and cost increments which are affected by the geothermal fluid chemistry. These include: (1) reservoir well casings, piping, pumps, steam separators, and associated equipment; (2) plant piping, heat exchangers, scrubbers, etc.; (3) reinjection systems, including wells, piping, and pumps; (4) equipment lifetimes and maintenance requirements for the reservoir, plant, and reinjection systems; and (5) processes for modifying the chemistry of the fluid, including gas removal, $\mathrm{pH}$ and other chemical shimming, as well as filtering and settling particulates in the plant effluents.

A study of the effects of geothermal fluid chemistry on plant operations and component costs is presented in a report prepared for this program. (8) This report, along with chemical industry data, provides the basis for estimating the cost effects of geothermal fluid chemistry.

The chemistry submodel computes process costs, process equipment capital costs, chemical disposal costs, and equipment capital, maintenance, and replacement costs as affected by system chemistry. Process requirements are treated as additional cost items in the plant capital and operating expenses. Plant and system equipment costs which are affected by fluid chemistry are treated as incremental costs over the base costs. Economic trade-offs exist for these items among initial investment, maintenance, and replacement lifetimes. The submodel, for instance, will analyze the trade-off between reinjection formation plugging, avoidance maintenance (such as hydrofracturing), and effluent filtration and treatment. 
At present the GEOCOST chemistry submodel is limited to the materials selection subroutines for reservoir and powerplant components described below. A similar set of models are under development for maintenance procedures, costs, and fluid treatment options; these are not yet suffi-. ciently refined to describe in this report.

\section{MATERIAL SELECTION FOR FIELD PIPING, WELL CASINGS, AND FIELD EQUIPMENT}

The material requirements for field piping, well casings, and field equipment are based primarily on the $\mathrm{pH}$. Other contaminants may have secondary effects on material selection, mainly in the maintenance category, and are treated in other portions of the chemistry submodel. Table 9 provides data for field equipment material selection.

\section{TABLE 9. Material Selection for Geothermal Field Equipment}

\begin{tabular}{|c|c|c|c|c|c|}
\hline Fluid & Temp. ${ }^{\circ} \mathrm{F}$ & pH & Material & $\begin{array}{l}\text { Cost } \\
\text { Factor } \\
\end{array}$ & $\begin{array}{l}\text { Years } \\
\text { Service } \\
\text { Life } \\
\end{array}$ \\
\hline Steam & A11 & NA & Carbon Stee ${ }^{(a)}$ & 1.0 & 30 \\
\hline Water & $200-400$ & $7+$ & Carbon Steel $(\mathrm{a})$ & 1.0 & 30 \\
\hline Water & $200-400$ & $6-7$ & $\begin{array}{l}\text { Lined } \\
\text { Steel or Similar } \\
\text { Clad Material }\end{array}$ & 2.0 & 10 \\
\hline Water & $200-400$ & $4-6$ & $\begin{array}{l}\text { Lined } \\
\text { Steel or Simi\}ar } \\
\text { Clad Material }\end{array}$ & 2.0 & 5 \\
\hline Water & $200-400$ & $<4$ & $\begin{array}{l}\text { Hastelloy C } \\
\text { or Similar Alloy }\end{array}$ & 10 & 30 \\
\hline \multicolumn{6}{|c|}{ Condensate and Reinjection Water } \\
\hline Water & $<200$ & $<4$ & Carbon Steel & 1.0 & 2 \\
\hline Water & $<200$ & $\begin{array}{l}\text { All } \mathrm{pH}^{\mathrm{b}}(\mathrm{b}) \\
\text { Cl Free }\end{array}$ & $\begin{array}{l}316 \text { Stainless } \\
\text { Steel }\end{array}$ & 2.0 & 30 \\
\hline Water & $<200$ & $<4$ & $\begin{array}{l}\text { Hastelloy C } \\
\text { or Similar Alloy }\end{array}$ & 10 & 30 \\
\hline Water & $<200$ & $4-6$ & Carbon Steel & 1.0 & 5 \\
\hline Water & $<200$ & $4-6$ & $\begin{array}{l}\text { Lined Carbon } \\
\text { Steel }\end{array}$ & 2.0 & 15 \\
\hline Water & $<200$ & $5-6$ & Carbon Steel & 1.0 & 15 \\
\hline Water & $<200$ & $7+$ & Carbon Steel & 1.0 & $30+$ \\
\hline
\end{tabular}

(a) Process equipment such as valves, flashers, and pumps are assumed to be constructed of materials with corrosion resistance superior to the base pipe material.

(b) $\mathrm{Cl}<50 \mathrm{ppm}$. 
MATERIAL SELECTION FOR POWERPLANT COMPONENTS

The material selection subroutine for the plant is based on the following:

(1) Flash Plant - A11 process plant components are exposed to flashed steam or steam condensate with the exception of plantlocated flashers (if used). Plant-located flashers will have the same requirements as the vapor generator cited in (2) below.

(2) Binary Plant - Only the vapor generator (boiler) and other process auxiliary heat exchangers are exposed to the geothermal fluid.

Table 10 provides material selection data for the geothermal powerplant. As in the case of field equipment, $\mathrm{pH}$ considerations generally dominate the selection of the appropriate material.

TABLE 10. Geothermal Powerplant Material Selection

\begin{tabular}{|c|c|c|c|c|c|c|}
\hline Fluid & $\begin{array}{c}\text { Contami- } \\
\text { nants } \\
\end{array}$ & $\begin{array}{l}\text { Temp. } \\
\left({ }^{\circ} \mathrm{F}\right)\end{array}$ & Components & Material & $\begin{array}{l}\text { Cost }(a) \\
\text { Factor }\end{array}$ & $\begin{array}{c}\text { Years } \\
\text { Service } \\
\text { Life } \\
\end{array}$ \\
\hline Water & $\mathrm{pH}>7$ & All & $\begin{array}{l}\text { Vapor Gen. \& } \\
\text { Aux. Ht. Ex. }\end{array}$ & Carbon Steel & 0.5 & 30 \\
\hline Water & $\mathrm{pH}<7$ & A11 & $\begin{array}{l}\text { Vapor Gen. \& } \\
\text { Aux. Ht. Ex. }\end{array}$ & $\begin{array}{l}\text { Ti or } \\
\text { Hastelloy C }\end{array}$ & 5 & 30 \\
\hline Steam & $\mathrm{H}_{2} \mathrm{~S}$ & Al1 & Turbine & $\begin{array}{l}\text { Special Blade } \\
\text { Material }\end{array}$ & 1.0 & 30 \\
\hline $\begin{array}{l}\text { Condensate } \\
\text { and Steam }\end{array}$ & $A 11^{(b)}$ & Al1 & $\begin{array}{l}\text { Plant Piping } \\
\text { Condensor, } \\
\text { Process Equip. }\end{array}$ & $\begin{array}{l}\text { Stainless } \\
\text { Steel, except } \\
\text { Condenser may } \\
\text { use Cu Alloy }\end{array}$ & 1.5 & 30 \\
\hline $\begin{array}{l}\text { Condensate, } \\
\text { Steam and } \\
\text { Water }\end{array}$ & Al1 & A11 & Gas Ejectors & $\begin{array}{l}\text { Lined Cast } \\
\text { Iron }\end{array}$ & 1.0 & 30 \\
\hline \multicolumn{7}{|c|}{$\begin{array}{l}\text { (a) Cost factors are multipliers of the basic cost equations for the } \\
\text { individual components. The cost factor often appears inconsistent } \\
\text { because the basic cost equation already reflects use of corrosion } \\
\text { resistant material.(s) of construction. }\end{array}$} \\
\hline 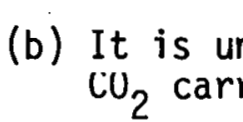 & $\begin{array}{l}\text { ikely } \\
\text { over. }\end{array}$ & st & and condensat & will have a $p$ & $>7$ due to & \\
\hline
\end{tabular}




\section{COMPUTER PROGRAM DESCRIPTION}

The GEOCOST computer program is written in FORTRAN IV extended for the Control Data CYBER 70 series computer system. The program currently requires 35,000 decimal words of computer memory and one disk file for storage of summary printout when executing consecutive cases. In addition to the standard FORTRAN library functions, a user generated steam library of subroutines on disk or tape is required to calculate a wide class of thermodynamic properties of water and steam. Typical execution time for one case is less than 10 seconds on the CYBER 74-18 computer with SCOPE 3.4.2 operating system.

The relatively low computer memory requirement was achieved by designing the program in modular fashion, with currently over 100 technical and economic subroutines and an additional 63 thermodynamic subroutines from the steam library. The modular design enables the user to select only those subroutines required to simulate the type of geothermal plant in which he is interested: dry steam, flashed steam, separated steam, binary, hybrid, or total flow. The subroutines selected by the user are then loaded into memory in six main parts called segments. The segmented loading enables certain parts of the program to reside in the same area of computer memory at different times to achieve the reduced memory requirement.

The segmented loading of the program is accomplished via the following tree structure:

where

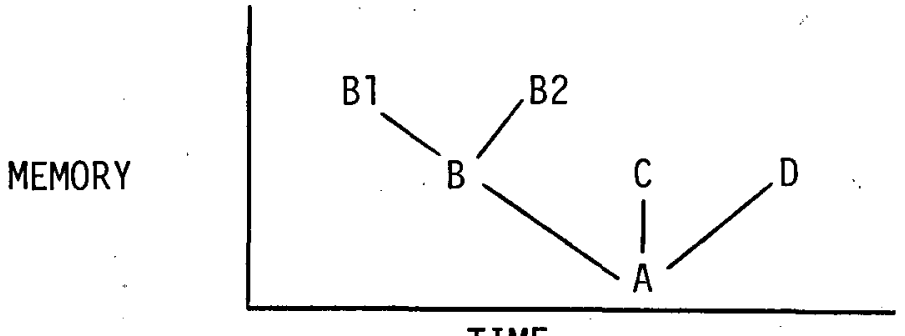

TIME

$A=$ Root segment

$B=$ Executive driver for powerplant systems and fluid transmission

$B 1=$ Powerplant systems

$B 2=$ Fluid transmission and disposal

$C=$ Reservoir

$D=$ Powerplant 
Representative values for the input data are initialized in a BLOCK DATA subroutine. These default values can be overridden for any simulation case by entering data through NAMELIST. Consecutive cases can be executed using the standard NAMELIST feature in which only those input data changing from the preceding simulation case require redefinition. As an alternative option, consecutive cases can also be generated internally in the program as combinations of selected parameters for parametric studies.

Printout options provide the following output: (1) comprehensive powerplant systems, fluid transmission, reservoir, and plant economic results, (2) powerplant systems and fluid transmission results only, or (3) reservoir and plant economic results only. Additionally, a summary of the final geothermal energy cost and its breakdown into reservoir and plant component costs is provided for each case when executing consecutive cases. 


\section{REFERENCES}

1. Robert Greider, "Economic Considerations for Geothermal Exploration in the Western United States," Chevron Oil Company, Denver, CO.

2. Marshall J. Reed, "The Economics of Geothermal Exploration," California Division of $0 \mathrm{il}$ and Gas, Sacramento, CA.

3. "Plan or Perish;" Drilling -DCW, p. 23, August 1974.

4. "NOISY1 - A Program for Calculation of Space Dependent Spectral Densities in Cubical Reactors," Nuclear Science and Engineering, p. 242, 1972.

5. A. L. Austin, G. N. Higgins, and J. H. Howard, The Total Flow Concept for Recovery of Energy from Geothermal Hot Brine Deposits, UCRL-51366, Lawrence Livermore Laboratory, Livermore, CA, Apri] 3, 1973.

6. J. J. Martin, "Equations of State," Ind. Eng. Chem., vol. 59, no. 12, pp. 34-52, 1967.

7. M. Benedict, G. B. Webb, and J. Rubin, J. Chem. Phys., vol. 8, p. 334, 1940.

8. D. W. Shannon, Economic Impact of Corrosion and Scaling Problems in Geothermal Energy Systems, BNWL-1866, Batte17e-Northwest, Richland, WA, September 1974.

\section{ACKNOWLEDGMENTS}

The authors gratefully acknowledge the technical contributions of Stacy Wise, Gary Seybold, Mike Cloninger, and other BNW staff members involved in this program. The editorial advice and assistance of Judy Harris in preparing this document are also appreciated. 
APPENDIX A

EXAMPLE PRINTOUT FROM GEOCOST 
An example summary printout from the GEOCOST code for a plant-located, two-stage, steam flashing cycle is shown in the following pages. More detailed printout is available at the user's option for the fluid transmission and powerplant systems as described earlier. The first page lists the characteristics of the reservoir and wells. All values are input except: MWt/We11, MWe/We11, producing wells on 7 ine, and total flow rate. The direct expenses associated with reservoir exploration, reservoir development, and reservoir operation are shown on page A.3. Other significant input economic factors for the reservoir and case identification information are listed on page A.4. Annual cash flow data for the major reservoir expenses are shown on page A.5. Summary accounts of deductible expenses are contained on page A.6. A simplified income statement is shown on page A.7 and the net cash flow and investment position is shown on page A.8. Page A.9 contains a summary of the costs of energy for the reservoir. In the right-hand column labeled distribution of energy costs, the taxes, royalty payments, and bond interest have been reallocated to the direct cost components for the reservoir. The rate of return on investment is included in the distributed energy cost for each component. The deductible nature of bond interest causes this expense to be partially included in the rate of return (the part which is included in the present worth factor) and the remainder to be accounted for separately. This completes the reservoir model.

Costs associated with the powerplant model begin on page $A .10$ with the powerplant capital costs. Pages A.11-A.15 contain the same economic and accounting information for the powerplant as pages A.4-A.8 for the reservoir. A summary of the total costs for the powerplant are shown on page A.16. All costs from the reservoir are included in the energy supply cost item. The energy supply costs are derived from the energy cost account shown on page A.12. This energy cost account is identical to the total power sales from the reservoir. The capacity penalty accounts for the portion of the cost associated with the in-house consumption of electricity. The difference between the unit cost for energy supply at the plant and the unit cost of energy from the reservoir is caused by the in-house consumption of electricity. As for the reservoir cost distribution, the taxes and bond interest have been reallocated to the primary cost components in the right-hand columns of the cost distribution. 
ECONOMIC ANALYSIS FOR GEOTHERMAL POWER

HIGH TEMPERA TURE-LOH SALINITY RESERVOIR

RESLRVOIR CHARACTERISTICS

AVEFAGE DEPTH

AVEFAGE TEMPËRTJRE

PROOUCING CAPACITY

WELL OESIGN (GVERAGE)

$$
\text { DEPTH }
$$

DOTTOM G TAMETÉ

FR̃CTION CASED

WELL PFCPERTIES (AVEZAGE)

MH(TH)/WELL

MW(E) /HELL

HELL LIFE

PRCUUCING WELLS ON LINE

OREY WELLS

INJECTION WELLS

WELL SPACING

DOW RATE/HELL

TOTAL FLOW RATE

WELL HEAD ORIGINAL FRESSURE

WELL HEAO OVER PRESSURE

FRACTION STEAM (HELLHEAD)

SIEAM SEPARATION (WELLHE
STEAMIFLASH MIX OPTION

HELLHEAŨ PRESSURE FACTOR

REDUCED PRESSURE FACTOK

STRAT IGFAPHY

RCCK TYPE DEPTH(H)

HARO 2800.0

FLUIO COMPOSITION
CACO3
NACL
SIO2
OTHER
TOTAL DISSOLVEC.

TOTAL DISSOLVEC SOLIOS

NONCONDENSIBLE GASES

$22.225 \quad \mathrm{CH}$

1.00

$76 \cdot 9$

800000.0 O/HR

10.0 YEARS

17.0

7.0

20.0 ACRES

034595.7 OHR

145.4 PSIA

166.8 PSIA

0.00

1

2.000

1.147
RESERVOIF ECGNOHIC DEVELOPMENT FACTORS

FAVORABLE TARGET FRACTION

FAVORABLE SITE FRACTION

FRACTION OF SITES TO EVALUATE

FRACTIOA OF SITES TC OFILL

FRACTION OF WELLS TO CASE
FRACTION OF SITES TO GEVELOP

PERCENT NONPROCUCING WELLS

TELL FLOW RATE

FRACTION EXCESS PROOUCING HELLS
$0.00 \times$

3.00

$\begin{array}{lll}0.00 & \% \\ 3.03 & x\end{array}$

272. PPM

$.070 \%$

$0.006 \%$ 
RESERVCIR EXPLORATIUN COSTS

\begin{tabular}{|c|c|}
\hline $\begin{array}{l}\text { TOTHL } \\
\text { COLLAKSI }\end{array}$ & $\begin{array}{r}\text { CVEING } \\
\text { MONTH/YEAE }\end{array}$ \\
\hline
\end{tabular}

IOENTIFICATION OF TARGETS PITERATURE SEARCH

PELIMINARY RECONNAISSANCE LITERATURE SEARCH

CHYCKSARCE

DCTAIILE LAND CMECK

DETAILE: RECONNAISSANUE

LEASE COST

GEOCHEMICAL EXXMINATION

DENTIFICATION OF ORILLABLE SITES

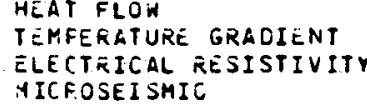

HEMFERATURE GRADIENT

ELECTRICAL RESISTIVITY

MICF.OSEI SHIC

JETAILEC GEOCHEMISTRY

EXFLORATION ORILLING

COST OF DRILLING

TOTAL EXPLOKATION COST -

FIELO OEV ELOPMENT

PRCOUCING WELLS

NONFRGDUCING WELLS

INUECTION WELLS

TRAASHISSION SYSTER

OIEFOSAL SYSTEM

TOTAL FIELD DEVELLPMENT COST

FIELC CFERATION

DEFLACEMENT WELL COST

WELL TRILLING COST

ABANOORMENT

WELL MAINTENANCE

WELL RECRILLING COST

INJECTION COST

INIJECTION WELT COST

TEANSMISSION SYSTEM MTE.

TRAKSMISSION SYSTEM MT
OISFOSAL SYSTEM MTE.

IODLLAKSI

(DULLAPS)

(OCLLARS) SITES

NT H Y YEAP

TOTL FIELD UPERATION COST

$\begin{array}{ll}2500 . & 20.0 \\ 6400 . & \equiv 0.0\end{array}$

8962.

$1200=$

$\equiv 0.0$

$2540 . ?$
$6350 . ?$

128.
128.

MAY 1970

CCT/1770

8023.2

t4. JUN 1970

334000
21000
25200

25200.
135000.

$$
\begin{aligned}
& 140.0 \\
& 230.0 \\
& 240.0
\end{aligned}
$$

12600.0

64.

JUN/ 197

$L E C / 1970$

372000.3

12930.0

1000.0

1200.0
5000.0

20000.0

24000.0

32. JUL/1970

JUL/1970
SEP/1970
SEF/197J

SEP/1970

$38400 . \quad 2400$

$\begin{array}{rr}38400 . & 2400.0 \\ 40000 . & 2530.0 \\ 11200 . & 700.0\end{array}$

16060.

2520.3
700.0

36000.0

21.

SEP/1970

MAY/1971

JUN $/ 1971$
JUN/ 1971

JUN 1971

$36000.5 \quad 16.0$ APR/1971 MAF/1973

$37500.0 \quad 16.0 \quad A P K / 1971$

$A F R / 197$

$\begin{array}{lll}15000.0 & 16 . & A P K / 1971 \\ 22500.0 & 16 . & A P R / 1971\end{array}$

MAR/1973

MAR/ 1973

MAR/ 1973

$255363 . \quad 13888.2$

$97 \div 243$.

$A P H / 1972$

MAR/ 1974

$\begin{array}{rlll}41474.8 & 4 . & A P K / 1972 & M A R / 1974 \\ 6000.0 & 4 . & \text { APR/1974 } & \text { APF/1974 }\end{array}$

43838.2

930404.8

1.00

TANGIBLE

INTANGIBLE

1923458.4
433605.5

2458231.
433806.

1022213.

3642659

534772.9
0.0

1012212.9

3042658.8

2014149.9

8961058 .

245823.
49165.
17000.

53477.3

77.3
0.0
0.0
0.0
0.0
0.0
0.0
0.0
0.0
0.0

192345.8

45.8
0.0
0.0
3.0
0.0
0.0
0.0
0.0
0.0
0.0

AFR/1974

$A P R / 1974$

OCT/1977

CEI/1977
COT/1977

SEP/1977

SEP $/ 1977$

$0 \leq C / 1979$

DEC/1979

C. C

OEC/1979

24000

161092.

40987 .

152133 .

100707 .

\section{JAN/1980}

JAN $/ 1980$

JAN/1980

JAN

JAN/1980

JAN

JAN 1980

JAN

JAN/1980
SAN/198J

DEC/200B

OEC/2008

DEC/2009

DEC/2009
OEC/2009

OEC/ 2009

DEC 12009

OEC 1500

$D E C / 2009$

$D E C / 2009$

55. MHE POWER PLANT IS . 20 CO OF TOTAL EXFLGRATION COST FGR THIS

TOTAL EXPLORATION COST ALLOCATEO TO THIS 275. HWE RESERVOIR FRODUCING CAPACITY 
INPUT DATA

EONO REPAYMENT PEOPCRTIONAL

SUM CF YEARS DIGITS DEFRECIATION

\begin{tabular}{|c|c|c|c|c|}
\hline 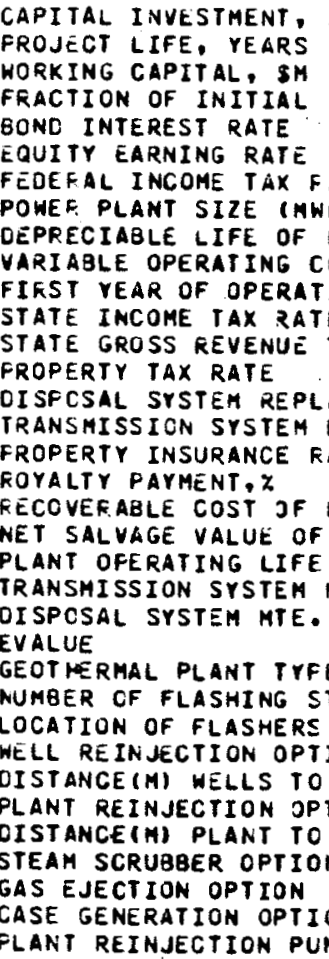 & 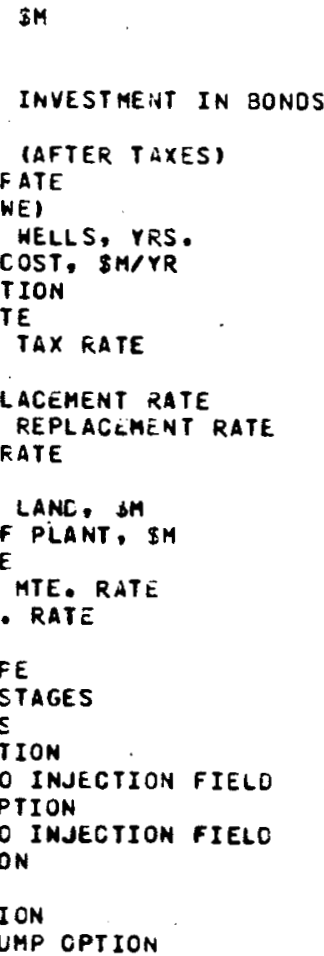 & $\begin{array}{r}6.6476 \\
40.0000 \\
0.0000 \\
.4200 \\
.0800 \\
.1500 \\
.4800 \\
55.0000 \\
10.0000 \\
0.0000 \\
1980 \\
.0700 \\
0.0000 \\
.0250 \\
.0900 \\
.0900 \\
.0012 \\
10.00 \\
0.0000 \\
0.0000 \\
30.0000 \\
.0500 \\
.0500 \\
.020090 \\
2 \\
2 \\
1 \\
0.00 \\
1000.0000 \\
1 \\
1000.0000 \\
1 \\
1 \\
0 \\
0\end{array}$ & IINITIAL & FINANCING) \\
\hline
\end{tabular}


EXPENSES IN SM/YE

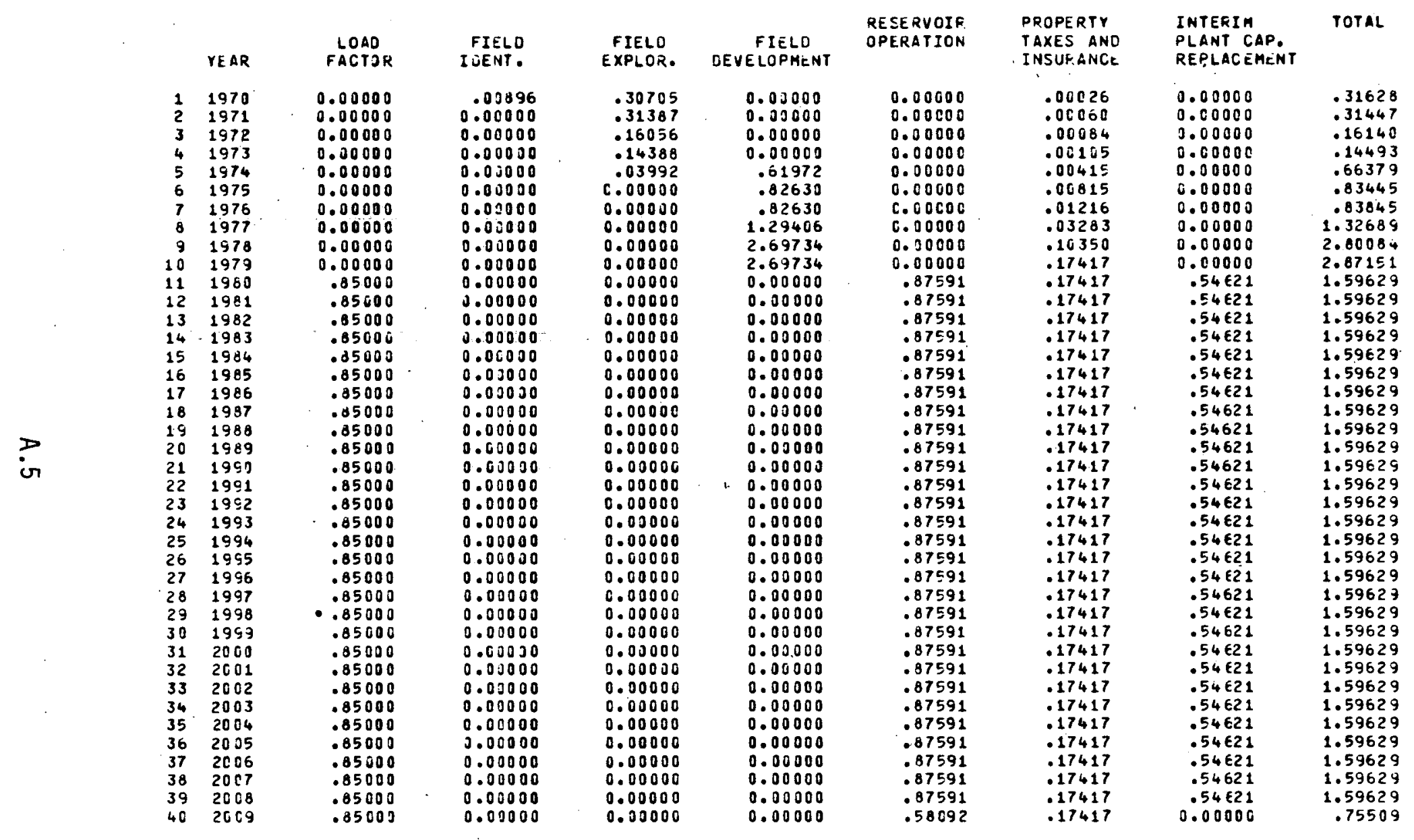


anNUAL CEDUCTIBLE EXPENSES, SH

10.325 PCT FIELO $\begin{array}{cc}\text { PRESENT } & \text { OPERATING } \\ \text { YEAR WORTH FACTOR EXPENSES }\end{array}$

RESERVCIF
HELL OEPLETION AMO

TOTAL

STATE $\begin{array}{lcc}\text { BOND } & \text { HELL OEPLETION AMO OEOUCTIBLE } & \text { INCOME } \\ \text { INTEREST DEPRECIATION OEPRECIATION OPER. EXF. } & \text { TAXES }\end{array}$

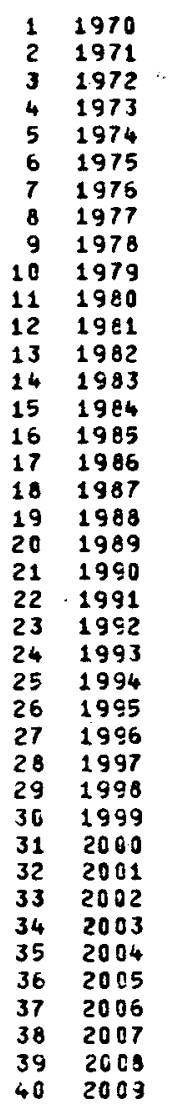

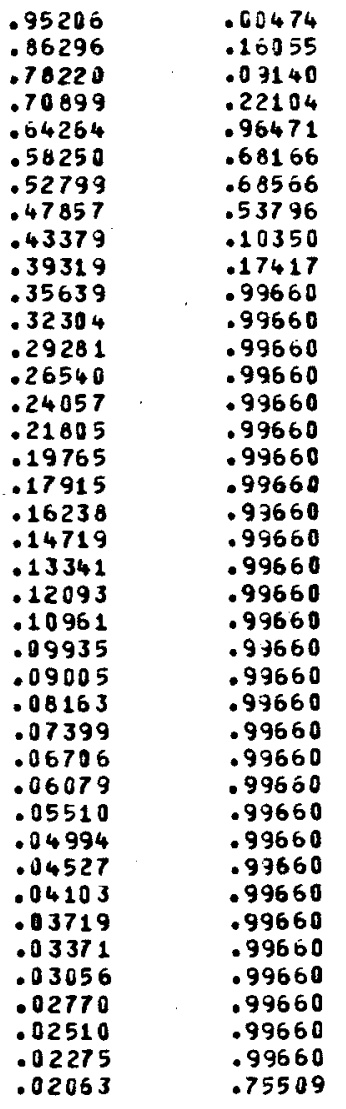

0.00000

0.00000 0.03000 0.00000 0.03000 0.00060 .01941 .02526 .03745 .05752

0.00000 0.00000 - 12322 0.00000

- 12322 0.00000

.22825
.34528

.34783 0.00000 .0323

.34138 .13223

$.33532 \cdots .10112$

.32963

.32426
.31918

.31434

.08848
.07779

.06963

.06223

$30969 \quad .05737$

. 30518

.05445

$.030074 \quad .05348$

$.29632 \quad .05348$

$.29184 \quad .05340$

$.28728 \quad .05348$

$\begin{array}{ll}.28257 & .05348 \\ .27766 & 005348\end{array}$

.27249 . 35348

$.26700 \quad .05348$

$.26110 \quad .05348$

$.25472 \quad .05340$

$\begin{array}{ll}.24777 & .05348 \\ .24013 & .05348\end{array}$

$.23172 \quad .05348$

$.22239 \quad .05348$

$.21203 \quad .05348$

.20047

. 18756

. 17311

.05348
.05348

.05348

.05348

.13880

.21391

0.000000

$-.00033$

.1714901198
0.00000

$0.00000 \quad-110610.001724$

$.00000 \quad .99361$
0.05555

$\begin{array}{lll}.71915 & -.05034\end{array}$

$0.00000 \quad .74318$

0.02672

0.00000

$.39301 \quad 1.83212$

$\begin{array}{lll}.39301 & 1.03212 & .13427 \\ .99211 & .09670\end{array}$

.847342 .30102

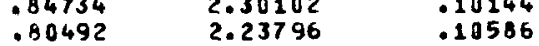

$.76465 \quad 2.17956 \quad .10995$

$.72713 \quad 2.12578 \quad .11371$

$.69176 \quad 2.07657 \quad 011716$

$.65874 \quad 2.03191 \quad .12020$

$.62807 \quad 1.99173 \quad .12309$

$.59975 \quad 1.95598 \quad 012560$

$\begin{array}{lll}.57378 & 1.92459 & .12779\end{array}$

$\begin{array}{lll}.55015 & 1.89654 & .12976 \\ .52080 & 1.87080 & .13156\end{array}$

$.50995 \quad 1.84731 \quad .13320$

$\begin{array}{lll}.49338 & 1.82602 & .13469\end{array}$

$\begin{array}{lll}.47915 & 1.80689 & .13603 \\ .46727 & 1.78984 & .13723\end{array}$

$.45775 \quad 1.77482 \quad .13828$

$\begin{array}{lll}.45057 & 1.76175 & .13919\end{array}$

$\begin{array}{lll}.44574 & 1.75054 & .13998\end{array}$

$.44326 \quad 1.74110 \quad .14064$

.4453501 .73714

1.72714

1.72238

$.46510 \quad 1.71654$

1.71535

014244

$.50800 \quad 1.71500 \quad 014247$

TOTALS $=$

2.08561

21.95301 
ANNUAL IMCOME STATEMENT, SM

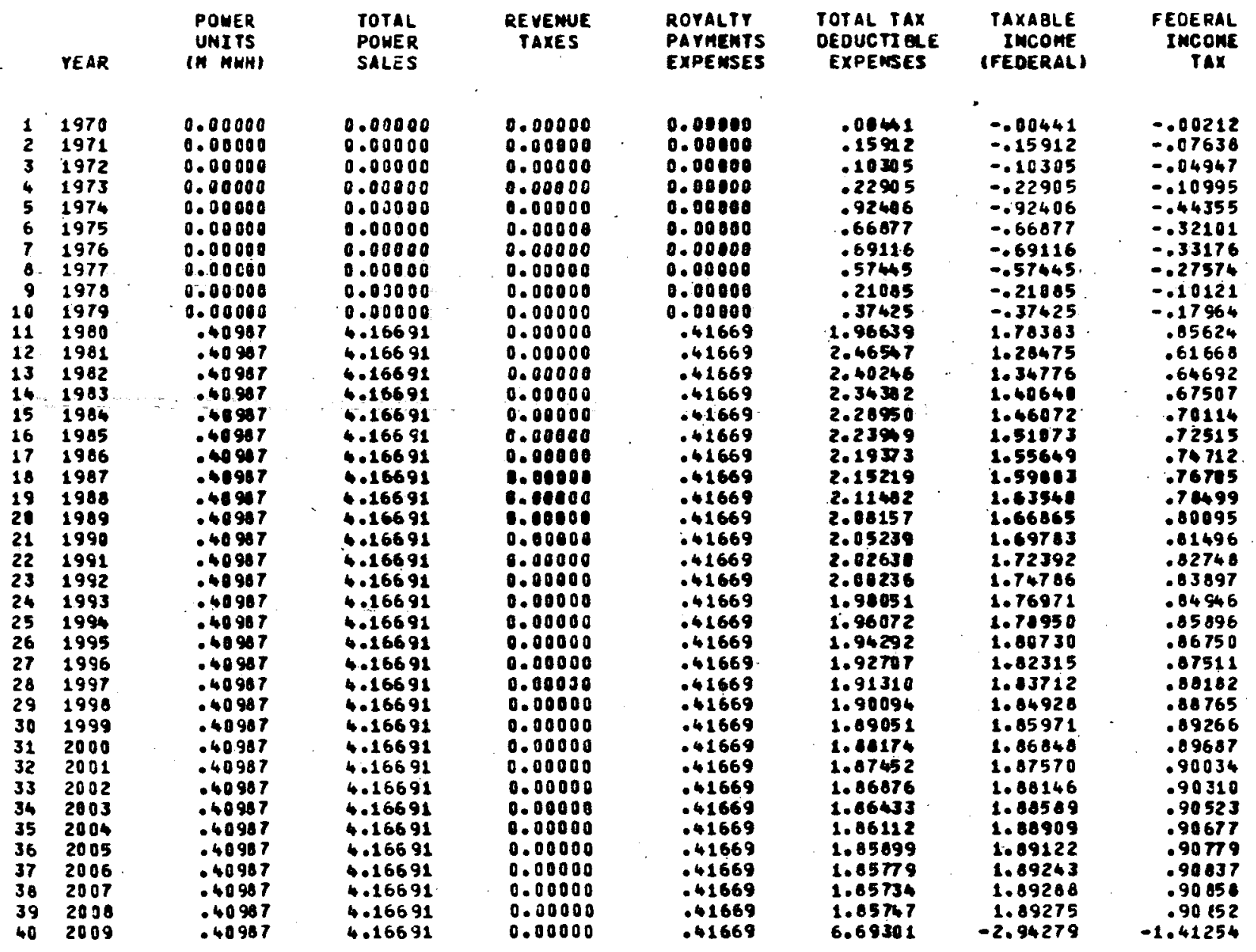


PAYOUT OF INVESTMENTS, \&H

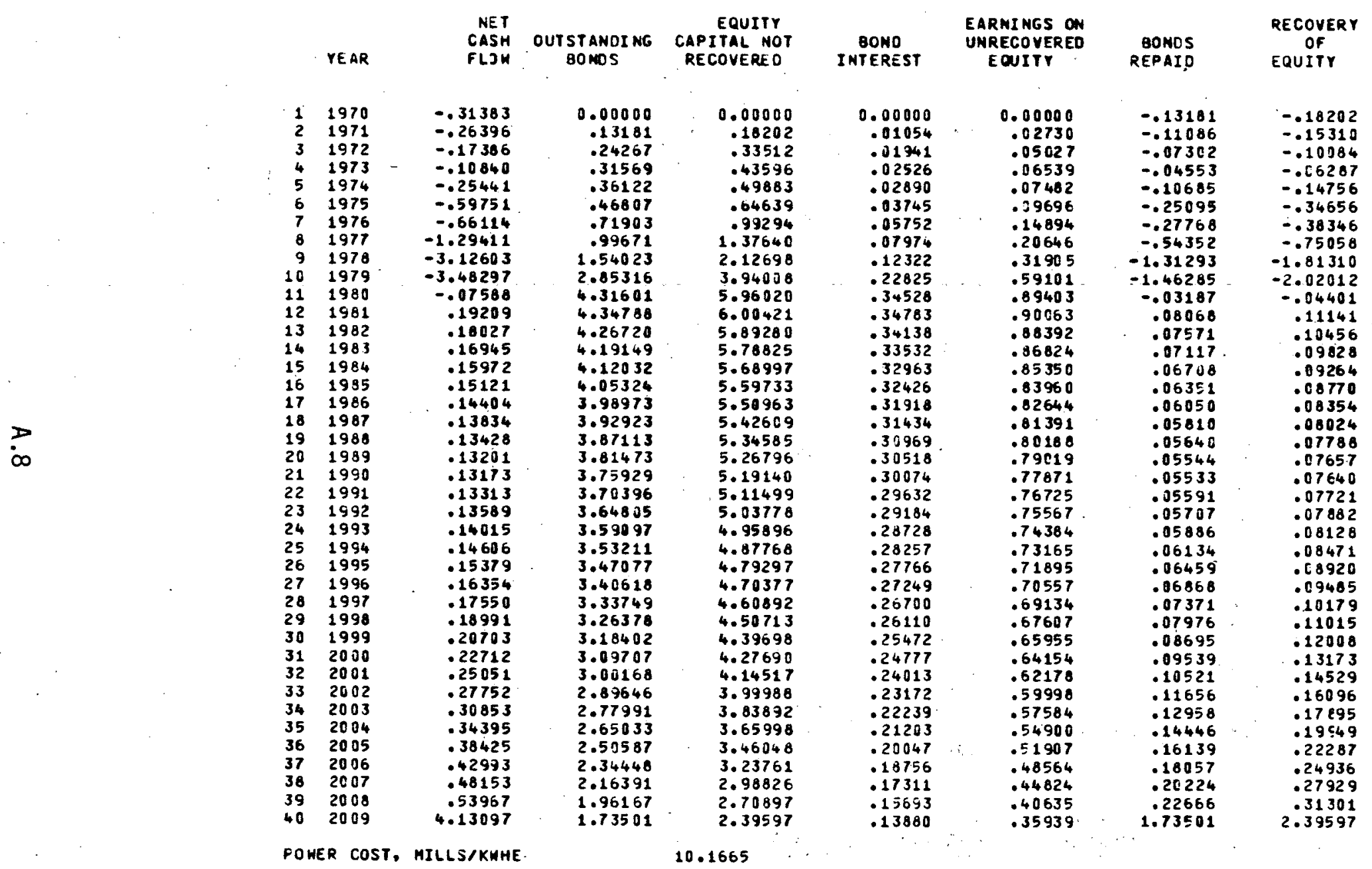


COST OF POWER

FIELO IOENTIFICATION AND EXPLORATION

FIELO DEVELOPMENT (TOTAL)

FIELO DENELOPHENT

PROOUCING MELLS

TRANSHISSION SYSTEM

OISFOSAL SYSTEM

NONPRODUCING NELLS

FIELD OFERATING COSTS ITOTALI

- oisposal costs

PROOUCING HELLS

TRANSHISSION COSTS

OTHER OPERATING COSTS

REVENUE TAXES

STATE INGOAE TAXES

ROYALTYPAYHENTS

FE OERAL. INCOME TAXES

BONOINATEREST
DETAILED GASH FLOW

MILLS

PER KNHE

ANNUAL

10.16650

.55700

2.81669

.92671

.06554

.06091

.16354

3.90102

1.00645

.90375

1.03548

1.03535

0.00000

.17668

1.01665

1.12669

.49096

1.50762

.08272

.41769

.13742

.12835

.12767

.02425

.59636

.14925

.13402

.15355

.15353

0.00000

.02620

.15076

.16708

.07281
DISTKIBUTION OF ENERGY COSTS

$$
\text { MILLS ANNUAL }
$$

PER KWHE (\$ MILLIONS)

$.74647 \quad .11070$

$4.46992 \quad .66286$

$1.15182 \quad .17081$

$1.57240 \quad .23318$

$1.56390 \quad .23193$

$.18171 \quad .02695$

$4.95012 \quad .73407$

$1.36077 \quad .20179$

$1.04464 \quad .15491$

$1.39432 \quad .20677$

$1.15039 \quad .17059$

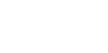


POMER PLANT CAPITAL COSTS

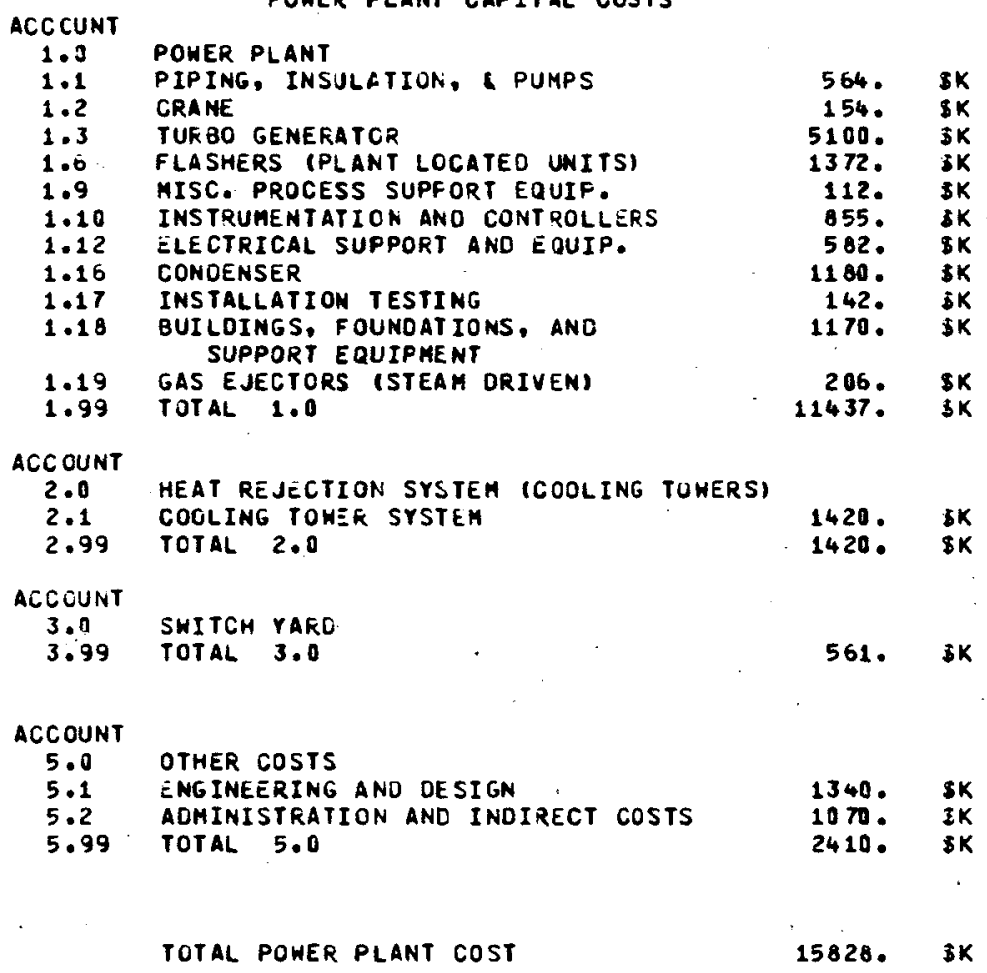

\section{ESTIMATEO COST -}

BASIS IS EXISTING PLANTS

IFLASH STEAM PLANTS ONLYI

9340. 5K 


\section{INPUT CATA}

BOND REPAYHENT PROPORTIONAL

SUA OF YEARS OIGITS OEPRECIATICA

FLANT INUESTMENT, SM

PROJECT LIFE, YEARS

15.8280

0.0000

0.080

BONO INTEREST RATE

INVESTHENT IN BONOS

ERUITY EARMTMG RATE (AFTER TAXESI

FEDERAL IMCOHE TAX RATE

$\stackrel{P}{=}$ $\begin{array}{ll}\text { PEOERAL INCOHE TAX RATE } & 55.0000 \\ \text { POWER PLANT SIIE (MWE) } & 35.0000\end{array}$

DEPRECIABLE LIFE OF PLANT, YRS.

STRCTION ANO LICENSING, YRS. 3.0000

VARIABLE OPERATING COST, SM/YR 0.0900

FIRST YEAR OF OPERATION

STATE INCOME TAX RATE

STATE GROSS REVENUE TAX RATE

FROPERTY TAX RATE

REPLACEMENTS, RATE/YR

FROPERTY INSURANCE RATE

ROYALTY PAYMENT, $X$

RECOVERABLE COST OF LANC: IM

MET SALVAGE VALUE OF PLANT, SH

FLANT OPERATING LIFE
1980
.0700

.0400

.0250

.0250

.0012

0.0000

0.0000

0.0000

30.0000
(INITIAL FINANCING)

(INITIAL FINANCING)

(AT 1OOX PLANT FACTOF,

(INITIAL FINANCING) 
CASH FLCM TABLE POWER FLANT, MILLIONS

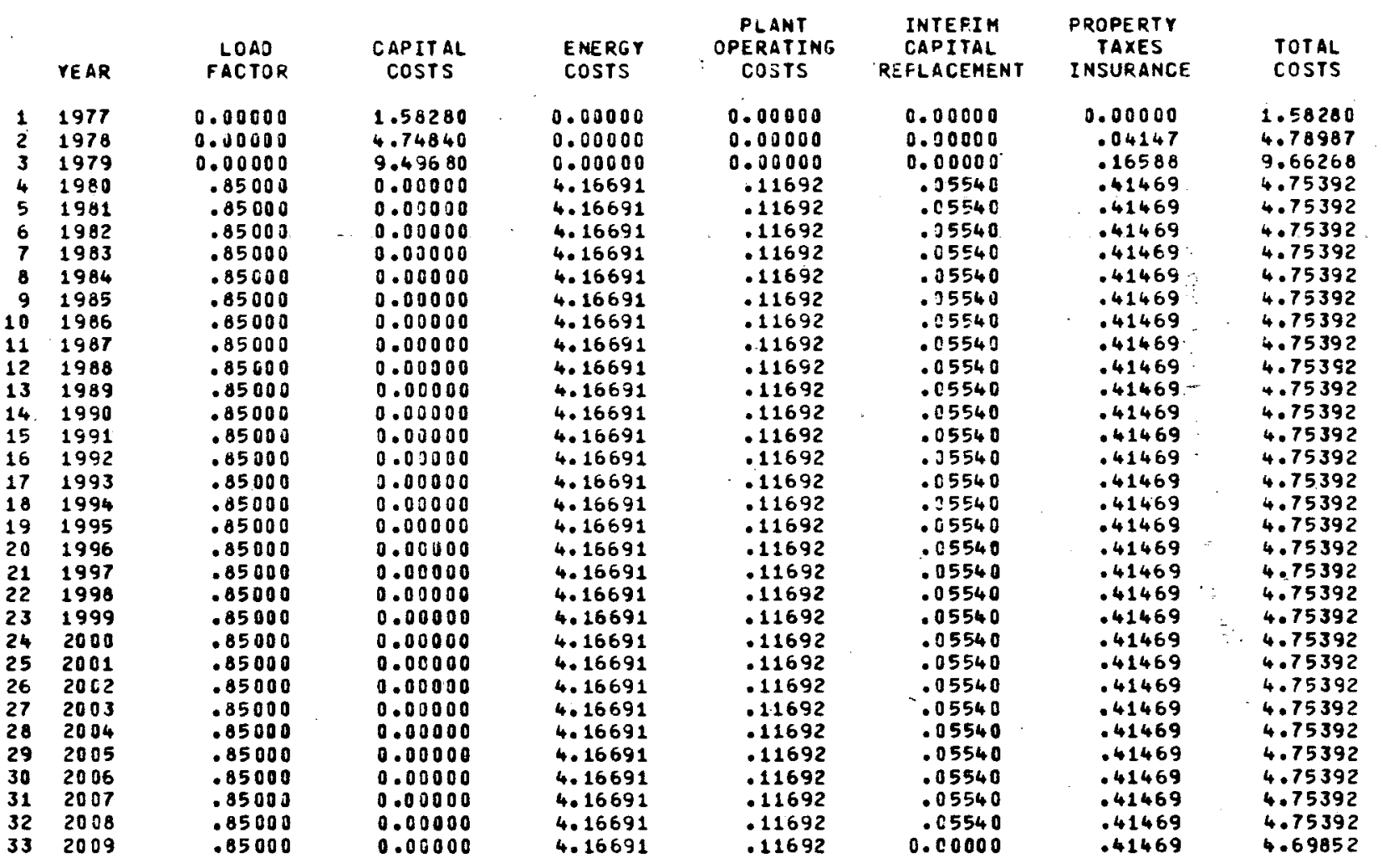


ANHUAL TAX DEOUCTIBLE EXPENSES, MILLICNS

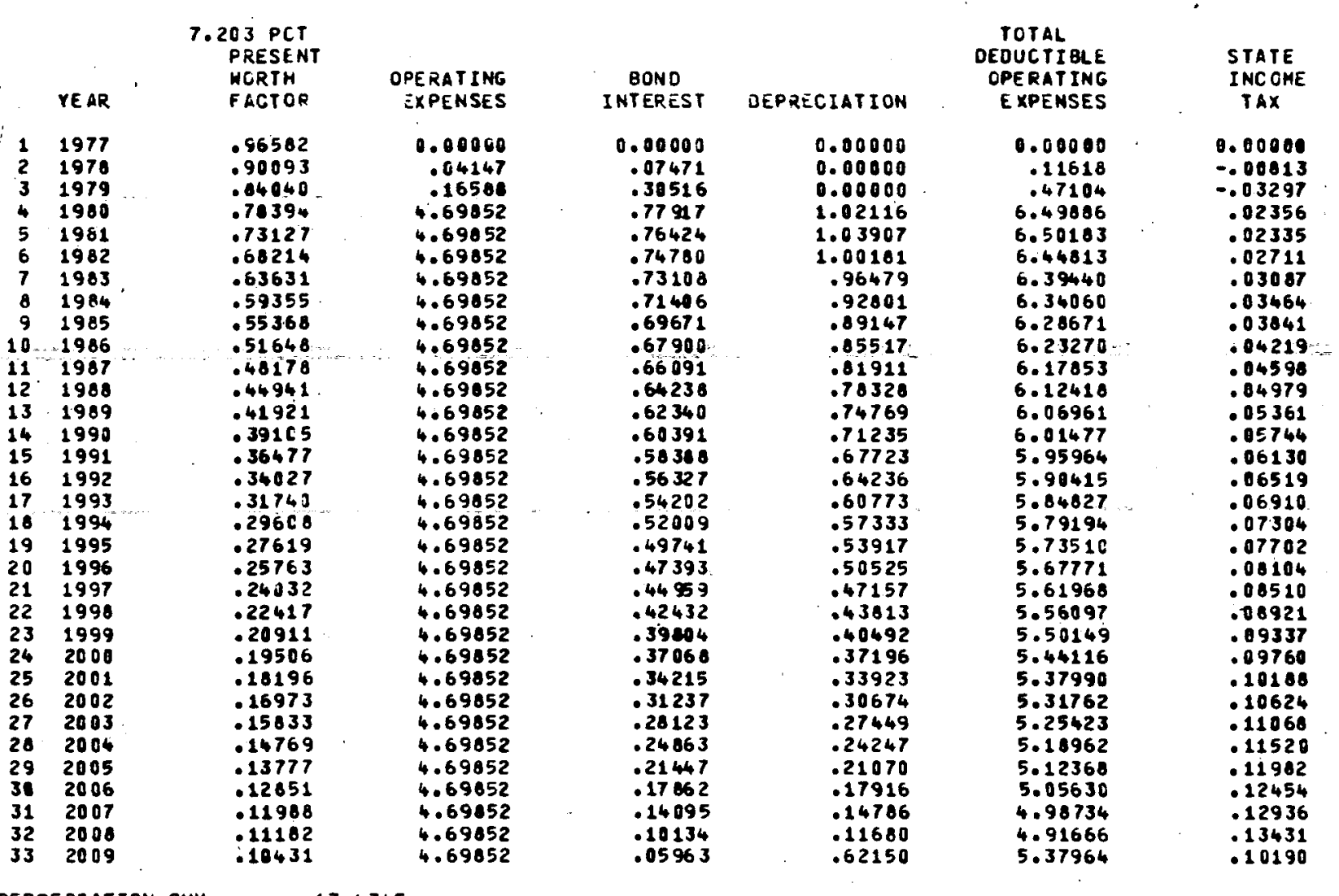


ANNUAL INCOME STATEMENT, MILLIONS

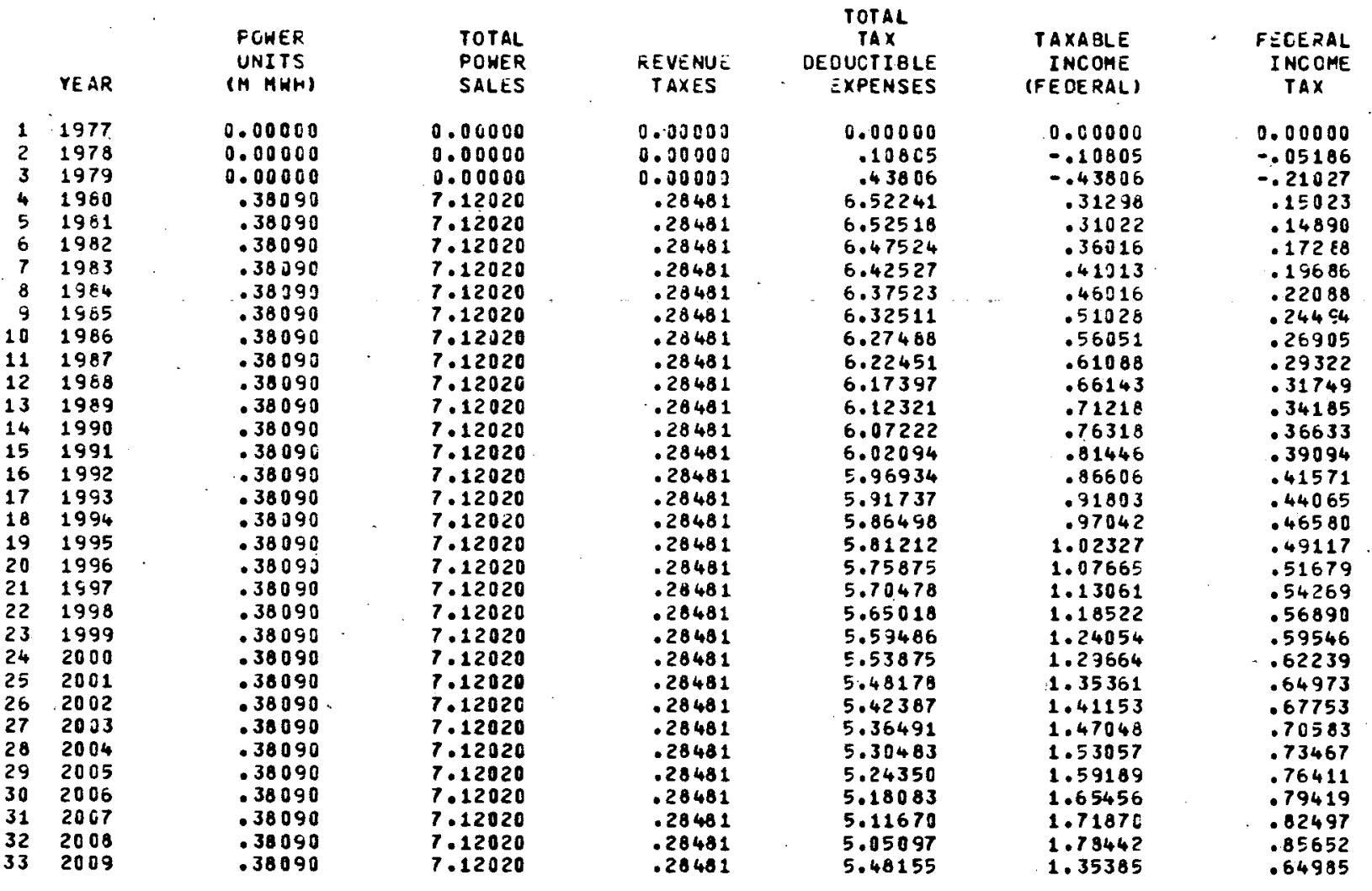


PAYOUT OF INVESTMENTS, MILLIONS

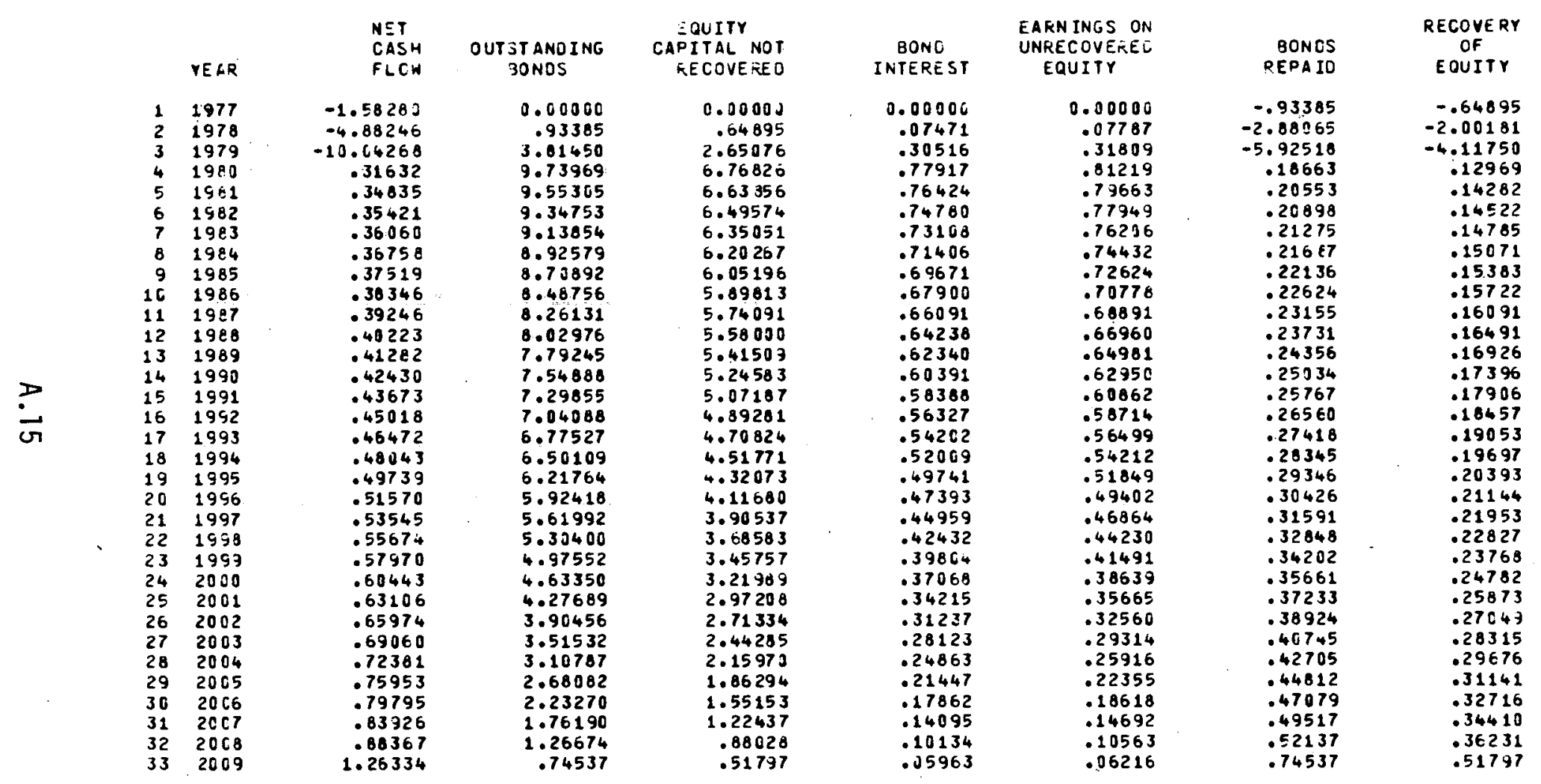


INSTALLEOCOOST

C S T OF POWEF

COST DISTKIGUTION

INITIAL PLANT

INTERIM CAPITAL REPLACEMENTS

ENEKGY SUPPLY

UPEKATING EXPENSES

FROPERTY TAXES AND INSURANCE

STATÉ REVENUE TAX

STATE INCOME TAX

FEDERAL INCOME TAX

BONO INTEREST

TOTAL

INTERNAL POWER CONSUMFTION
287.78182

- per kme

\section{DETAILEO CASH FLOH}

$$
\text { PER KWHR }
$$

MILLIONSI

18.69309

5.62920

MILLS

PILLS

CASH FLOH

ANNUAL

18.69339

5.62310

$\begin{array}{llll}3.54194 & 1.06659 & 5.63475 & 1.68777 \\ .14396 & .04335 & .19177 & .05775 \\ 10.93963 & 3.29428 & 11.39545 & 3.43154 \\ .30694 & .09243 & .31973 & .09628 \\ 1.13413 & .34152 & 1.18138 & .35575 \\ .14772 & .22516 & & \\ .14020 & .04222 & & \\ .89407 & .26923 & . & \\ .84443 & .25430 & & \\ 18.69309 & 5.62910 & 18.69305 & \\ 1.32108 & .39782 & & \end{array}$


No. of

Copies

OFFSITE

1 AEC Chicago Patent Group

U.S. Atomic Energy Commission Argonne, IL 60439

A. A. Churm

15 Division of Applied Technology Geothermal Energy Branch

U. S. Atomic Energy Commission

Washington, D. C. 20545

L. B. Werner

143 AEC Technical Information Center

Department of Petroleum

Engineering

Stanford University

Stanford, CA 94305

William Brigham

2 Geothermal Energy Studies

National Science Foundation

1800 G Street

Washington, D. C. 20550

R. B. Coryell

P. Kruger

Geology \& Geotechnology Branch

D. S. Bureau of Reclamation

P. 0. Box 25007, D.F.C.

Denver, CO 80225

Jerry S. Dodd, Chief

Office of Naval Research

536 South Clark Street

Chicago, IL 60605

Dr. Forrest L. Dowling

Westinghouse Electric Corp.

700 Braddock Avenue

East Pittsburgh, PA 15112

W. H. Comtois,

Generation Consultant
California Division of $0 i 1$ and Gas

Sacramento, CA 95814

Marshal1 J. Reed, Ass't. Geothermal Officer

Garrett Research \& Development Co. 1855 Carrion Road

LaVerne, CA 91750

Edward F. Waht

UW-Extension

Engineering Department

432 North Lake Street

Madison, WI 53706

Robert C. Lutton, Program Director

Commonwealth Assoc., Inc. $209 \mathrm{E}$. Washington Avenue

Jackson, MI 49201

Richard J. Berger

Sargent \& Lundy Engineers

$55 \mathrm{E}$. Monroe Street

Chicago, IL 60603

J. M. Clinch, Supervisor

Advanced Analys is

3 Lawrence Livermore Lab.

P. 0. Box 808

Livermore, CA 94551

Lawrence B. Owen

Arthur L.: Austin

Phillip Johnson

Sandia Corp.

Albuquerque, NM 87115

G. Brandvold

Gibbs \& Hill, Inc.

8404 Indian Hills Drive

Omaha, NB 68114

Raul Ramos 
No. of

Copies

Morton Salt Company

1275 Lake Avenue

Woodstock, IL. 60098

Howard Fiedelman, Director

Commission Federal de Electridad

Dept. of Geothermal Resources

Mexico 5, D. F. Mexico

$\mathrm{Mr}$. Jorge Guiza

Reed Tool Company

P. 0. Box 2119

Houston, TX 77001

K. W. Jones, New Products

Development Engineer

Electric Power Research Institute

3412 Hillview Ave.

Palo Alto, CA 94304

Duane Spencer

Phillips Petroleum Company

Box 752

Del Mar, CA 92014

Richard C. Lenzer

Fenix \& Scisson Inc.

P. 0. Box 15408

Las Vegas, NV 89114

Robert Littiejohn

Reynolds Metals Co.

P. 0. Box 27003

Richmond, VA 23261

Wilson D. Michel1

CER Geonuclear Corp.

P. 0. Box 15090

Las Vegas, NV 89114

KeithK. Millheim

Oak Ridge National Laboratory

Oak Ridge, TN 37830

R. Lyon

Chevron $0 i 1$ Company

Denver, CO

R. Greider
No. of

Copies

Chemical Energy \& Geo-Sciences Branch

U. S. Atomic Energy Commission

Washington, D. C. 20545

David M. Richman, Chief

1706 Wens ley Avenue

El Centro, CA 92243

Matt Ternes

International Salt Company

Clarks Summit, PA 18411

$H$. Leigh Woehling, VP-Resource Dept.

Dresser Industries 601 Jefferson, P. 0. Box 6504 Houston, TX 77005

R. M. Wolke, Mgr., Geothermal Projects

U. S. Steel Corp.

600 Grant St., Rm. 2737

Pittsburgh, PA 15230

Fredrick Wright

Pacific Gas \& Electric Co.

77 Beale

San Francisco, CA 94105

John Finney

Alaska Resources Library

$U$. S. Department of Interior

555 Cordova St.

Anchorage, AK 99501

J. D. Gibson

3801 B West, 44th Avenue

Anchorage, AK 99503

w. Ogle

U. S. Department of Interior Office of Geochemistry \& Geophysics

345 Middlefield Road

Menlo Park, CA 94025

L. J. P. Muffler 
No: of

Copies

Rodgers Engineering Co., Inc. 16 Beale

San Francisco, CA 94105

J. Kuwada

Lawrence Berkeley Laboratory

Berkeley, CA 94720

Kenneth F. Mirk

Portland General Electric Co.

621 S. W. A.lder

Portland, OR 97205

$\mathrm{Ne} i l \mathrm{H}$. Woodley

TRW

One Space Park

Redondo Beach, CA 90278

R. 0. Pearson

Bureau of Reclamation

Boulder City, NV 89005

Wayne A. Fernelius
No. of

Copies

Aerojet Nuclear Company

550 2nd Street

Idaho Falls, ID 83401

Jay F. Kunze

Los Alamos Scientific Laboratory

P. 0. Box 1663

Los Alamos, NM 87544

Morton C. Smith

Washington Public Power Supply System Richland, WA 99352

W. C. Wolkenhauer

3 Jet Propulsion Lab. 4800 Oak Grove Drive

Pásadena, CA 91103

Leonard Jaffe

Daniel Kerrisk

J. Doane

\section{ONSITE}

1 AEC Richland Operations Office

55. Battelle - Northwest

C. H. Bloomster (15)

J. B. Burnham

D. J. Braun

L. L. Clark

M. Clement

M. O. Cloninger

P. D. Cohn

B. W. Cone

J. W. Currie

D. E. Deonigi

J. G. Desteese

R. L. Dillon

P. J. Dionne

L. E. Erickson

T. J. Foley

J. C. Fox

J. L. Harris

H. D. Huber

W. S. Kelly

P. N. LaMori

K. W. McGinnis

R. W. McKee

W. McSpadden

T. B. Powers

S. A. Rao

R. G. Rau

W. A. Reardon

D. W. Shannon

J. R. Sheff

D. L. Stewart

L. T. Pederson

R. A. Walter

K. E. Yandon

J. R. Young

Economics Library (3)

Technical Information (3)

Technical Publications (1) 